\title{
DAMPAK KEBIJAKAN MAKROEKONOMI DAN FAKTOR EKSTERNAL EKONOMI TERHADAP LAJU DEFORESTASI DAN DEGRADASI HUTAN ALAM: STUDI KASUS DEFORESTASI UNTUK PERLUASAN AREAL TANAMAN PANGAN DAN PERKEBUNAN SERTA HUTAN TANAMAN INDUSTRI DAN DEGRADASI HUTAN ALAM AREAL KONSESI
}

(Macroeconomic Policy and Economic External Factor Impact on Natural Forest Degradation and Deforestation Rates: Case Study of Deforestation for Food and Estate Crops and Industrial Plantation Forest Areas Expansion and Degradation on Natural Forest Concession Areas)

\author{
Oleh/By: \\ Satria Astana ${ }^{1}$, Bonar M. Sinaga ${ }^{2}$, Sudarsono Soedomo ${ }^{3}$, Bintang C.H. Simangunsong ${ }^{4}$ \\ ${ }^{1}$ Puslitbang Perubahan Iklim dan Kebijakan, Jalan Gunung Batu 5, PO Box 272, Bogor 16610 \\ ${ }^{2,3,4}$ Fakultas Kehutanan Insitut Pertanian Bogor Kampus IPB Darmaga Bogor, Tlp 0251-622640
}

Diterima 3 Januari 2012, disetujui 7 Juni 2012

\begin{abstract}
In forestry subsector, reducing $\mathrm{CO}_{2}$ emission can be conducted by maintaining and conserving the remaining natural forest area and/or increasing the existing plantation forest area through replanting the degraded forest area. The effectiveness of such policy is affected by forest external factors. In this research, the forest external factors analysed are limited to: (1) macroeconomic policy, and (2) economic external factors. The objective of this research is to analyse the impact of macroeconomic policy and economic external factor on natural forest degradation and deforestation rates. Using an econometric model, the results of this research indicate that the natural forest degradation and deforestation rates are influenced by the changes in macroeconomic policy and economic external factor. In this regard, the interest rate is the significant transmission channel of the policy and economic external factor and therefore it can be used as an effective incentive-disincentive policy instrument to control the natural forest degradation and deforestation rates.
\end{abstract}

Keywords: Macroeconomic policy, external factor, natural forest, degradation, deforestation

\begin{abstract}
ABSTRAK
Di subsektor kehutanan, pengurangan emisi $\mathrm{CO}_{2}$ dapat diwujudkan dengan mempertahankan dan mengkonservasi hutan alam yang tersisa dan/atau meningkatkan hutan tanaman yang ada dengan mereboisasi kawasan hutan yang terdegradasi. Efektivitas kebijakan tersebut dipengaruhi oleh faktor eksternal hutan. Dalam penelitian ini, faktor eksternal hutan yang dianalisis dibatasi pada: (1) kebijakan makroekonomi dan (2) faktor eksternal ekonomi. Penelitian ini bertujuan untuk menganalisis dampak kebijakan makroekonomi dan faktor eksternal ekonomi terhadap laju deforestasi dan degradasi hutan alam. Menggunakan model ekonometrika, hasil analisis mengindikasikan bahwa laju deforestasi dan degradasi hutan alam dipengaruhi oleh kebijakan makroekonomi dan faktor eksternal ekonomi. Dalam
\end{abstract}


hal ini, suku bunga merupakan saluran transmisi kebijakan dan faktor eksternal ekonomi yang signifikan dan karenanya dapat digunakan sebagai instrumen kebijakan insentif-disinsentif yang efektif untuk mengendalikan laju deforestasi dan degradasi hutan alam.

Kata kunci: Kebijakan makroekonomi, faktor eksternal, hutan alam, degradasi, deforestasi

\section{PENDAHULUAN}

Perekonomian dunia sedang berubah menghadapi setidaknya tiga fenomena perubahan. Pertama adalah fenomena perubahan yang ditandai oleh semakin terintegrasinya pasar modal dan keuangan serta perdagangan. Perubahan kondisi moneter internasional ditransmisikan ke dalam perekonomian suatu negara melalui sistem finansial dan perdagangan. Dalam kasus yang ekstrim, hubungan ketergantungan tersebut ditunjukkan oleh adanya krisis di suatu negara merembet ke negara lain. Sebagai contoh, krisis keuangan di Amerika Serikat pada tahun 2008 memicu terjadinya krisis finansial dunia. Kedua adalah fenomena perubahan yang ditandai oleh lompatan kenaikan harga minyak mentah dunia (MMD). Harga MMD meningkat dari USD 3 per barel menjadi USD 10 per barel pada tahun 1970 -an, kemudian dari USD 15 per barel menjadi USD 40 per barel pada awal tahun 1980-an (Pangestu, 1986), dan dari USD 20 per barel pada awal tahun 2000 menjadi USD 90 per barel pada akhir tahun 2000-an. Ketiga adalah isu perubahan iklim global. Isu perubahan iklim global merupakan isu dunia yang kini menjadi perhatian banyak kalangan baik di dalam negeri maupun di dunia internasional. Selaras dengan isu tersebut, perhatian masyarakat internasional terhadap perkembangan masalah deforestasi dan degradasi hutan semakin tinggi.

Ketiga fenomena tersebut berdampak pada perekonomian suatu negara dan masingmasing negara perlu melaksanakan penyesuaian pada seluruh lini sektor ekonomi. Dengan kata lain, kondisi perekonomian dunia dapat dipandang sebagai kondisi yang sedang mengalami proses penyesuaian bukan saja berkaitan dengan pasar dunia yang semakin terintegrasi dan lompatan kenaikan harga MMD namun juga berkaitan dengan isu perubahan iklim, yang dampaknya terhadap masa depan perekonomian belum banyak dimengerti. Hal ini menyarankan pentingnya mempelajari bukan hanya pengaruh kebijakan makro ekonomi dan faktor eksternal ekonomi (suku bunga dan harga MMD) terhadap pertumbuhan ekonomi, namun penting juga mempelajari dampak kebijakan makro ekonomi dan faktor eksternal terhadap perubahan iklim, termasuk laju deforestasi dan degradasi hutan alam.

Hutan memiliki pengaruh penting pada iklim (Contreras-Hermosilla et al., 2007). Jika jumlah tanaman dan pepohonan berkurang (akibat deforestasi), maka jumlah $\mathrm{CO}_{2}$ di atmosfer yang diserap akan berkurang (Ross, 1998 dalam Alimov, 2002). Deforestasi dipandang sebagai salah satu penyebab pemanasan global. FAO (2005) melaporkan bahwa kehilangan hutan global masih tinggi, yang pada periode 2000 - 2005 mencapai 7,3 juta ha per tahun. Pusat Inventarisasi dan Perpetaan Kehutanan (2008) melaporkan bahwa laju deforestasi di Indonesia mencapai 1,87 juta ha pada periode 1990 - 1996 dan kemudian meningkat menjadi 3,51 juta ha pada periode 1996 - 2000. Pada periode 2000 - 2003, laju deforestasi di Indonesia menurun menjadi 1,08 juta ha dan kemudian meningkat kembali menjadi 1,17 juta ha pada periode 2003 - 2006. Menurut Kaimowitz dan Angelsen (1998), terdapat kesepakatan yang luas bahwa ekspansi areal tanaman budidaya (cropped area) serta 
penggembalaan (pasture) merupakan sumber utama deforestasi.

Melalui kerangka REDD (Reducing Emission from Deforestation and Forest Degradation in Developing Countries), Indonesia pada tahun 2009 mendeklarasikan target pengurangan emisi $\mathrm{CO}_{2}$ sebesar $26 \%$ hingga tahun 2020, dan menetapkan subsektor kehutanan berkontribusi menurunkan sebesar 14\%. Di subsektor kehutanan, pengurangan emisi $\mathrm{CO}_{2}$ dapat diwujudkan dengan mempertahankan dan mengkonservasi hutan alam yang tersisa dan/atau meningkatkan hutan tanaman yang ada dengan mereboisasi kawasan hutan yang terdegradasi. Pertanyaannya adalah apakah kebijakan tersebut akan efektif dapat mengurangi ekspansi areal tanaman budidaya pada hutan alam? Wunder dan Verbist (2003) menyatakan bahwa pengaruh eksternal hutan (tropis) lebih dominan dibanding pengaruh internal hutan. Dengan kata lain, dampak faktor eksternal hutan misalnya sektor lain sering lebih penting dibanding dampak faktor internal hutan misalnya undang-undang di bidang kehutanan, proyek penanaman pohon secara partisipatif atau program pendidikan lingkungan. Menyadari bahwa ruang lingkup faktor eksternal hutan adalah luas, penelitian ini membatasi pada dua faktor, yaitu: (1) kebijakan makroekonomi, dan (2) faktor eksternal ekonomi. Selaras dengan permasalahan tersebut, penelitian ini bertujuan untuk menganalisis dampak kebijakan makroekonomi dan faktor eksternal ekonomi terhadap laju deforestasi dan degradasi hutan alam.

\section{A. Analisis Dampak Kebijakan Makro- ekonomi dan Faktor Eksternal Ekonomi}

Kebijakan makroekonomi yang dianalisis terdiri dari: (1) kebijakan moneter yakni penawaran uang, dan (2) kebijakan fiskal yakni pengeluaran pemerintah. Faktor eksternal ekonomi yang dianalisis terdiri dari: (1) suku bunga Amerika Serikat (Federal Fund Rate), dan (2) harga minyak mentah dunia. Pengaruh kebijakan makroekonomi dan faktor eksternal ekonomi terhadap perekonomian suatu negara dapat melalui beberapa saluran. Terdapat empat saluran transmisi yang umum dipahami, yaitu: (1) saluran suku bunga (interest rate channel), (2) saluran kredit (credit channels), (3) saluran harga asset (asset channel), dan (4) saluran nilai tukar (exchange rate channels) (Norrbin, 2000; Ireland, 2006). Untuk mendeteksi pengaruh perubahan moneter terhadap harga dan output perekonomian penting memahami apakah melalui jalur finansial atau jalur neraca perdagangan (trade balance). Mekanisme transmisi moneter pada intinya menjelaskan bagaimana perubahan stok uang yang disebabkan oleh kebijakan moneter atau dampak suku bunga jangka pendek pada peubah riel, seperti output agregat dan penyerapan tenaga kerja (Ireland, 2006). Keempat saluran tersebut dapat juga digunakan untuk menjelaskan pengaruh kebijakan makroekonomi dan faktor eksternal terhadap laju deforestasi dan degradasi hutan alam, namun dalam penelitian ini, hanya saluran suku bunga yang dikaji. Suku bunga secara langsung mempengaruhi laju deforestasi dan degradasi hutan alam melalui pengaruhnya terhadap permintaan input lahan hutan alam dan secara tidak langsung melalui pengaruhnya terhadap permintaan dan penawaran atau harga komoditas yang dihasilkan.

Dengan pemikiran tersebut, suku bunga diperlakukan sebagai peubah endogen ${ }^{5}$. Gambar 1 menjelaskan keseimbangan pasar uang. Keseimbangan pasar uang dipengaruhi oleh penawaran uang (MS/P) dan permintaan

\footnotetext{
Sebagai peubah endogen, keseimbangan suku bunga dapat dianalisis berdasarkan keseimbangan parsial pasar uang (money market), pasar barang (good market), dan eksternal (balance of payment), serta berdasarkan keseimbangan umum (keseimbangan internal): pasar uang dan pasar barang, dan keseimbangan umum: internal dan eksternal, bergantung pada tujuan analisis dan asumsi yang digunakan.
} 
uang L(r,Y); r adalah suku bunga dan Y adalah PDB (Produk Domestik Bruto). Gambar 2 menjelaskan pengaruh penawaran uang terhadap suku bunga. Dari Gambar 2 diketahui bahwa dengan asumsi faktor-faktor lain tidak berubah, kenaikan penawaran uang $\left(\mathrm{MS}_{0} / \mathrm{P}\right.$ ke $\left.\mathrm{MS}_{1} / \mathrm{P}\right)$ atau penurunan penawaran uang $\left(\mathrm{MS}_{1} / \mathrm{P}\right.$ ke $\left.\mathrm{MS}_{0} / \mathrm{P}\right)$, akan menyebabkan suku bunga menurun $\left(\mathrm{r}_{0}\right.$ ke $\left.\mathrm{r}_{1}\right)$ atau meningkat $\left(r_{1}\right.$ ke $\left.r_{0}\right)$. Penurunan atau kenaikan suku bunga yang terjadi menyebabkan permintaan uang meningkat atau menurun, yang menyebabkan PDB meningkat $\left(\mathrm{Y}_{0}\right.$ ke $\left.\mathrm{Y}^{*}{ }_{0}\right)$ atau menurun $\left(\mathrm{Y}^{*}{ }_{0}\right.$ ke $\left.Y_{0}\right)$. Dengan kata lain, kenaikan atau penurunan penawaran uang akan menggeser kurva LM (keseimbangan pasar uang) ke kanan atau ke kiri, yang menyebabkan suku bunga menurun atau meningkat, dan PDB meningkat atau menurun. Dengan demikian, dapat dihipotesiskan bahwa peningkatan penawaran uang akan menurunkan suku bunga, dan penurunan suku bunga akan meningkatkan laju deforestasi dan menurunkan laju degradasi. Sebaliknya penurunan penawaran uang akan menaikkan suku bunga, dan kenaikkan suku bunga akan menurunkan laju deforestasi dan menaikkan laju degradasi.

Pengaruh kebijakan fiskal yakni pengeluaran pemerintah terhadap laju deforestasi dan degradasi hutan alam dapat dijelaskan menggunakan Gambar 1 dengan memasukkan konsep national income account identity (NIAI). Konsep NIAI menyatakan bahwa PDB (Produk Domestik Bruto) (Y) merupakan penjumlahan dari konsumsi, investasi, pengeluaran pemerintah, dan ekspor bersih (net export). Dengan konsep NIAI, maka dengan asumsi faktor-faktor lain tidak berubah, peningkatan atau penurunan pengeluaran pemerintah akan menyebabkan PDB meningkat atau menurun. Dari Gambar 1

\footnotetext{
${ }^{6}$ Berdasarkan konsep NIAI dapat diturunkan kurva IS yakni kurva yang mengilustrasikan keseimbangan pasar barang: kombinasi $\mathrm{Y}$ dan $\mathrm{r}$ yang memenuhi NIAI (Mankiw, 2000).
}

diketahui bahwa peningkatan atau penurunan PDB akan menggeser kurva permintaan uang ke atas $\left[\mathrm{L}\left(\mathrm{r}_{0}, \mathrm{Y}_{0}\right)\right.$ ke $\left.\mathrm{L}\left(\mathrm{r}_{1}, \mathrm{Y}_{1}\right)\right]$ atau ke bawah $\left[\mathrm{L}\left(\mathrm{r}_{1}, \mathrm{Y}_{1}\right)\right.$ ke $\left.\mathrm{L}\left(\mathrm{r}_{0}, \mathrm{Y}_{0}\right)\right]$, yang menyebabkan suku bunga meningkat $\left(r_{0}\right.$ ke $\left.r_{1}\right)$ atau menurun $\left(r_{1}\right.$ ke $\left.r_{0}\right)$. Dengan demikian, dapat dihipotesiskan bahwa peningkatan pengeluaran pemerintah akan menaikkan suku bunga, dan kenaikan suku bunga akan menurunkan laju deforestasi dan menaikkan laju degradasi. Sebaliknya penurunan pengeluaran pemerintah akan menurunkan suku bunga, dan penurunan suku bunga akan meningkatkan laju deforestasi dan menurunkan laju degradasi.

Pengaruh faktor eksternal ekonomi yakni suku bunga Amerika Serikat terhadap perekonomian Indonesia juga dapat dijelaskan dengan menggunakan Gambar 1 dan konsep NIAI tetapi dengan memasukkan konsep keseimbangan eksternal ekonomi. Dalam hal ini, keseimbangan eksternal ekonomi dinyatakan dengan mengendogenkan peubah nilai tukar Rupiah (Rupiah/US\$). Keseimbangan nilai tukar Rupiah dipengaruhi antara lain secara negatif oleh perbedaan suku bunga dalam negeri dan Amerika Serikat (uncovered interest parity) dan juga secara negatif oleh ekspor bersih. Ekspor bersih dipengaruhi antara lain secara positif oleh nilai tukar Rupiah, dan secara negatif oleh harga minyak mentah dunia. Dengan demikian, dengan asumsi faktor-faktor lain tidak berubah, kenaikan atau penurunan suku Amerika Serikat akan mendepresiasi (menaikkan) atau mengapresiasi (menurunkan) nilai tukar Rupiah. Depresiasi atau apresiasi nilai tukar Rupiah akan menaikkan atau menurunkan ekspor bersih. Dari konsep NIAI diketahui bahwa kenaikan atau penurunan ekspor bersih akan menaikkan atau menurunkan PDB. Kenaikan atau penurunan PDB, dari Gambar 1

\footnotetext{
${ }^{7}$ Hal ini karena sejak tahun 2004, Indonesia telah menjadi oil net importing country.
} 
diketahui, akan menggeser kurva permintaan uang ke atas $\left[\mathrm{L}\left(\mathrm{r}_{0}, \mathrm{Y}_{0}\right)\right.$ ke $\left.\mathrm{L}\left(\mathrm{r}_{1}, \mathrm{Y}_{1}\right)\right]$ atau ke bawah $\left[\mathrm{L}\left(\mathrm{r}_{1}, \mathrm{Y}_{1}\right)\right.$ ke $\left.\mathrm{L}\left(\mathrm{r}_{0}, \mathrm{Y}_{0}\right)\right]$, yang menyebabkan suku bunga meningkat $\left(r_{0}\right.$ ke $\left.r_{1}\right)$ atau menurun $\left(r_{1}\right.$ ke $\left.r_{0}\right)$. Dengan demikian, dapat dihipotesiskan bahwa kenaikan suku bunga Amerika Serikat akan menaikkan suku bunga dalam negeri, dan kenaikan suku bunga dalam negeri akan menurunkan laju deforestasi dan meningkatkan laju degradasi. Sebaliknya penurunan suku bunga Amerika Serikat akan menurunkan suku bunga dalam negeri, dan penurunan suku bunga dalam negeri akan meningkatkan laju deforestasi dan menurunkan laju degradasi.

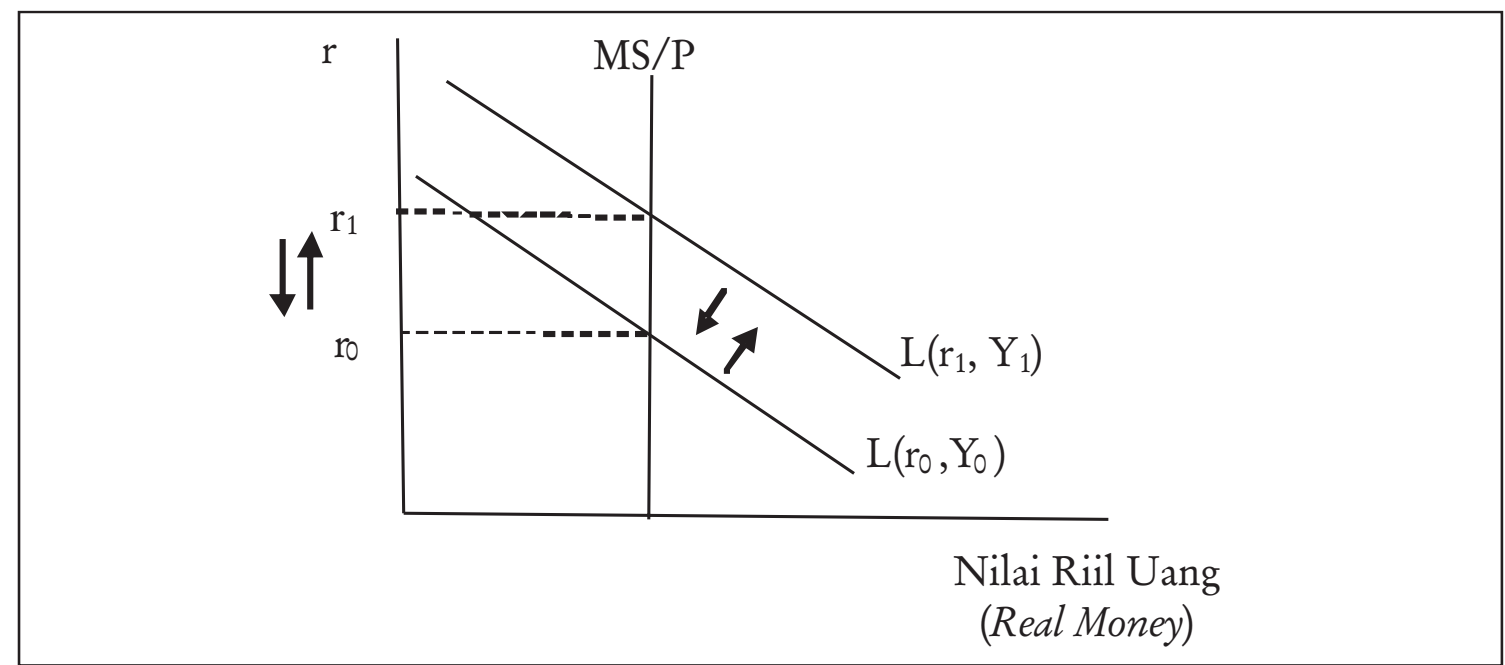

Sumber (Source): Modifikasi dari (Modified from) Suranovic, 2008

Gambar 1. Keseimbangan pasar uang

Figure 1. Money market equilibrium

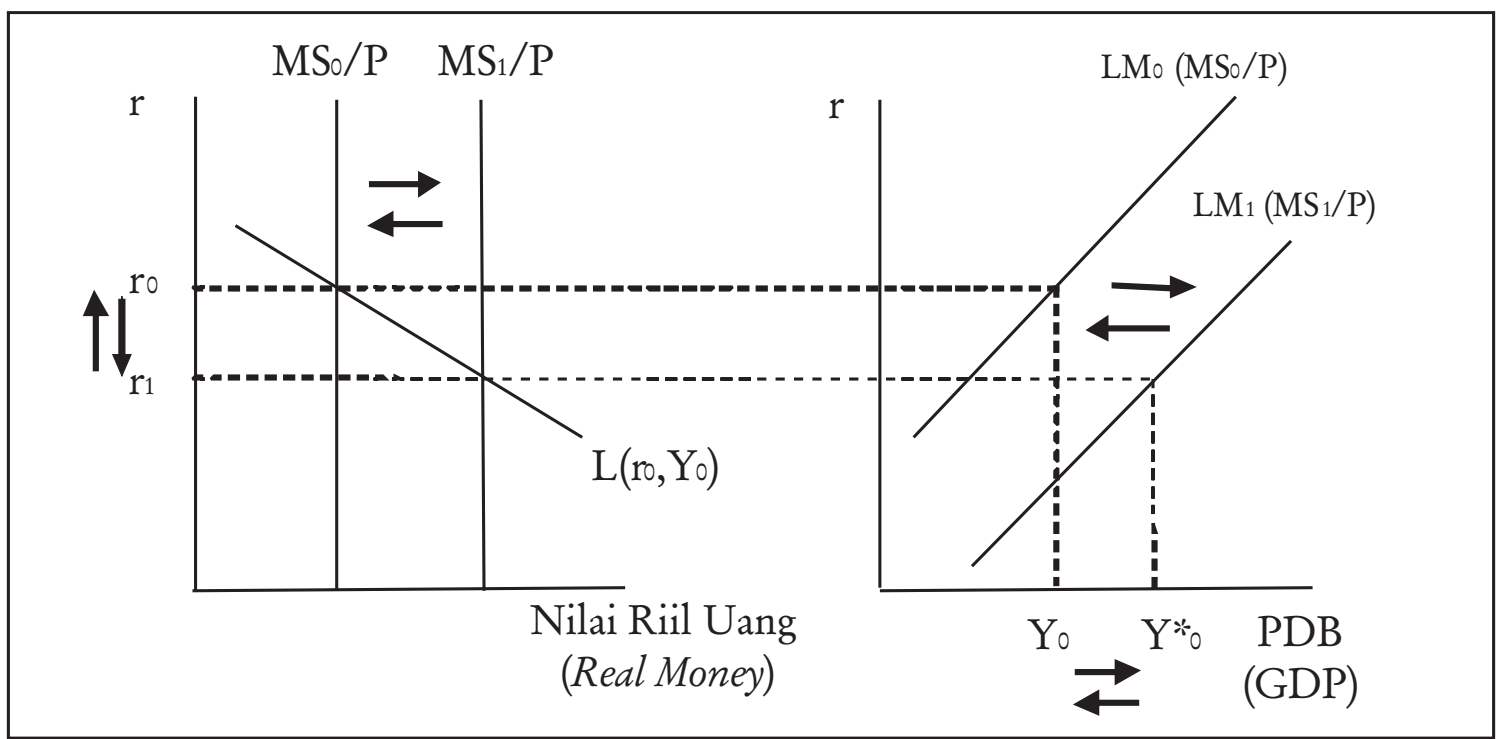

Gambar 2. Pengaruh penawaran uang terhadap suku bunga di pasar uang Figure 2. Effect of money supply on interest rate in money market 
Pengaruh faktor eksternal ekonomi yakni harga minyak mentah dunia terhadap perekonomian Indonesia juga dapat dijelaskan dengan menggunakan Gambar 1 dan konsep NIAI dan dengan memasukkan konsep keseimbangan eksternal ekonomi. Dalam hal ini, harga minyak mentah dunia dihipotesiskan mempengaruhi secara positif pengeluaran pemerintah $^{8}$, dan mempengaruhi secara negatif ekspor bersih. Dengan demikian, dengan asumsi faktor-faktor lain tidak berubah, kenaikan harga minyak mentah dunia akan meningkatkan pengeluaran pemerintah, dan menurunkan ekspor bersih. Dari konsep NIAI diketahui bahwa jika net effect-nya terhadap PDB bernilai positif, maka kenaikan harga minyak mentah dunia akan menaikkan PDB, dan jika bernilai negative akan menurunkan PDB. Dari Gambar 1 diketahui bahwa kenaikan atau penurunan PDB akan menggeser kurva permintaan uang ke atas $\left[\mathrm{L}\left(\mathrm{r}_{0}, \mathrm{Y}_{0}\right)\right.$ ke $\left.\mathrm{L}\left(\mathrm{r}_{1}, \mathrm{Y}_{1}\right)\right]$ atau ke bawah $\left[\mathrm{L}\left(\mathrm{r}_{1}, \mathrm{Y}_{1}\right)\right.$ ke $\left.\mathrm{L}\left(\mathrm{r}_{0}, \mathrm{Y}_{0}\right)\right]$, yang menyebabkan suku bunga domestik meningkat $\left(r_{0}\right.$ ke $\left.r_{1}\right)$ atau menurun $\left(\left(r_{1}\right.\right.$ ke $\left.r_{2}\right)$. Dengan demikian, dapat dihipotesiskan bahwa kenaikan harga minyak mentah dunia dapat menaikkan atau menurunkan suku bunga domestik. Kenaikan suku bunga domestik akan menurunkan laju deforestasi dan meningkatkan laju degradasi, sedangkan penurunan suku bunga domestik akan meningkatkan laju deforestasi dan menurunkan laju degradasi.

\section{B. Analisis Deforestasi dan Degradasi Hutan Alam}

1. Analisis deforestasi hutan alam

FAO (2000) mendefinisikan hutan: " $a$ forest is an area of a minimum $0.5 \mathrm{ha}$, covered by

\footnotetext{
${ }^{8}$ Kenaikan harga minyak mentah dunia menyebabkan harga atau biaya subsidi minyak untuk konsumsi minyak dalam negeri meningkat, karena Indonesia sejak tahun 2004 telah menjadi net importer minyak. Kenaikan biaya subsidi minyak menyebabkan pengeluaran pemerintah meningkat.
}

a tree canopy of at least 10\%, with trees that can reach more than $5 m$ height, and subject to the constraint that the area should not be under an alternative (e.g. agricultural or urban) use". Menurut Wounder dan Verbist (2003), dalam terminologi FAO ini, hutan alam dan hutan tanaman dipertimbangkan sebagai hutan (sepanjang memenuhi kerita kuantitatif), sementara agroforestry dipertimbangkan sebagai non-forest system ketika tujuan utamanya adalah untuk memproduksi agricultural outputs. Berdasarkan pemahaman tersebut, Wounder dan Verbist (2003) men-definisikan deforestasi sebagai perubahan kondisi hutan sehingga arealnya tidak layak lagi dikualifikasikan sebagai hutan. Menurut Wounder dan Verbist (2003), dalam banyak kasus, deforestasi terjadi karena areal tutupan tajuknya berkurang dari 10\% melalui konversi untuk penggunaan lahan selain hutan, yang dapat bersifat permanen (misalnya: urban expansion) atau temporer (misalnya: per-ladangan berpindah). Pusat Inventarisasi dan Perpetaan Kehutanan (2008) mendefinisikan deforestasi sebagai perubahan kondisi penutupan lahan dari kelas penutupan lahan kategori hutan (berhutan) menjadi kelas penutupan lahan kategori nonhutan (tidak berhutan). Dalam penelitian ini, pengertian hutan merujuk pada pengertian hutan alam bukan hutan buatan (hutan tanaman), sehingga areal HTI (Hutan Tanaman Industri) digolongkan ke dalam areal deforestasi (hutan alam).

Dengan pengertian tersebut, laju deforestasi hutan alam dianalisis menggunakan teori permintaan input produksi. Permintaan input produksi dalam hal ini permintaan input lahan hutan alam (LHA) dipandang sebagai permintaan input untuk memproduksi suatu komoditas. Penawaran LHA diproksi menggunakan luas LHA. Dengan pemikiran ini, model pasar LHA dapat dikonstruksi. Gambar 2 menjelaskan model keseimbangan pasar LHA. Dalam jangka pendek, penawaran LHA diasumsikan upward sloping, yang pada 
Gambar 2 ditunjukkan oleh kurva $\mathrm{OK}^{9}$. Dalam jangka panjang, LHA berubah menjadi lahan dengan beragam pemanfaatan, karena luas LHA seluruhnya telah dimanfaatkan. Dengan berubahnya LHA menjadi lahan dengan beragam pemanfaatan, penawaran LHA berubah menjadi penawaran lahan. Selama penawaran lahan tidak berubah dengan berubahnya harga lahan, kurva penawaran LHA dalam jangka panjang digambarkan dengan kurva tegak lurus, yang pada Gambar 2 ditunjukkan oleh kurva KS. Pada Gambar 2, keseimbangan pasar LHA dalam jangka pendek ditunjukkan oleh titik $\mathrm{P}$, dan dalam jangka panjang, titik K.

Dalam jangka pendek, harga pasar LHA $^{10}$ ditentukan oleh kekuatan penawaran dan permintaannya. Permintaan input LHA merupakan permintaan input yang akan dimanfaatkan untuk memproduksi suatu komoditas. Permintaan input LHA dipengaruhi oleh harganya, harga output, dan faktorfaktor yang lain, seperti harga input selain LHA dan kebijakan pemerintah. Termasuk ke dalam input selain LHA, antara lain: harga kapital (suku bunga), harga tenaga kerja (upah), dan harga energi. Harga kapital atau suku bunga merupakan harga input selain LHA yang menjadi fokus kajian. Kebijakan makroekonomi dan faktor eksternal ekonomi akan mempengaruhi suku bunga, dan perubahan suku bunga secara langsung akan mempengaruhi laju deforestasi melalui pengaruhnya terhadap permintaan input LHA. Dalam hal ini, permintaan input LHA diasumsikan sebagai laju deforestasi untuk perluasan areal tanaman sebagai upaya pengembangan produksi suatu komoditas.

Untuk memudahkan analisis, penawaran LHA (OK) diasumsikan eksogen, sehingga dalam jangka pendek, harga pasar LHA hanya dipengaruhi oleh faktor-faktor yang mempengaruhi permintaan input LHA. Faktor-faktor yang mempengaruhi permintaan input LHA, merupakan peubah eksogen atau shifter yang menentukan keseimbangan harga input LHA. Perubahan faktor-faktor tersebut akan menggeser kurva permintaan LHA $\left(D^{\text {LHAS }}\right)$ ke kiri atau ke kanan. Dalam hal ini, pergeseran kurva $\mathrm{D}^{\text {LHAS }}$ ke kiri menunjukkan terjadi penurunan laju deforestasi hutan alam untuk perluasan areal produksi suatu komoditas dan sebaliknya pergeseran kurva $D^{\text {LHAS }}$ ke kanan menunjukkan terjadi peningkatan laju deforestasi. Laju deforestasi hutan alam yang dianalisis dibatasi pada permintaan input LHA untuk perluasan areal: (1) tanaman sawit, (2) tanaman karet, (3) tanaman padi, dan (4) HTI.

${ }^{9}$ Kebijakan moratorium izin pemanfaatan hutan alam primer pada dasarnya merupakan upaya untuk menggeser kurva OK ke kiri.

${ }^{10}$ Data harga input LHA tidak tersedia, sehingga dalam model diasumsikan eksogen. Dalam model, harga input LHA dalam kasus unit usaha yang tidak terintegrasi vertikal dengan industri pengolahan direfleksikan oleh harga komoditas yang dihasilkan, sedangkan dalam kasus unit usaha yang terintegrasi vertikal dengan industri pengolahan oleh harga output hasil pengolahan dari komoditas yang dihasilkan. 


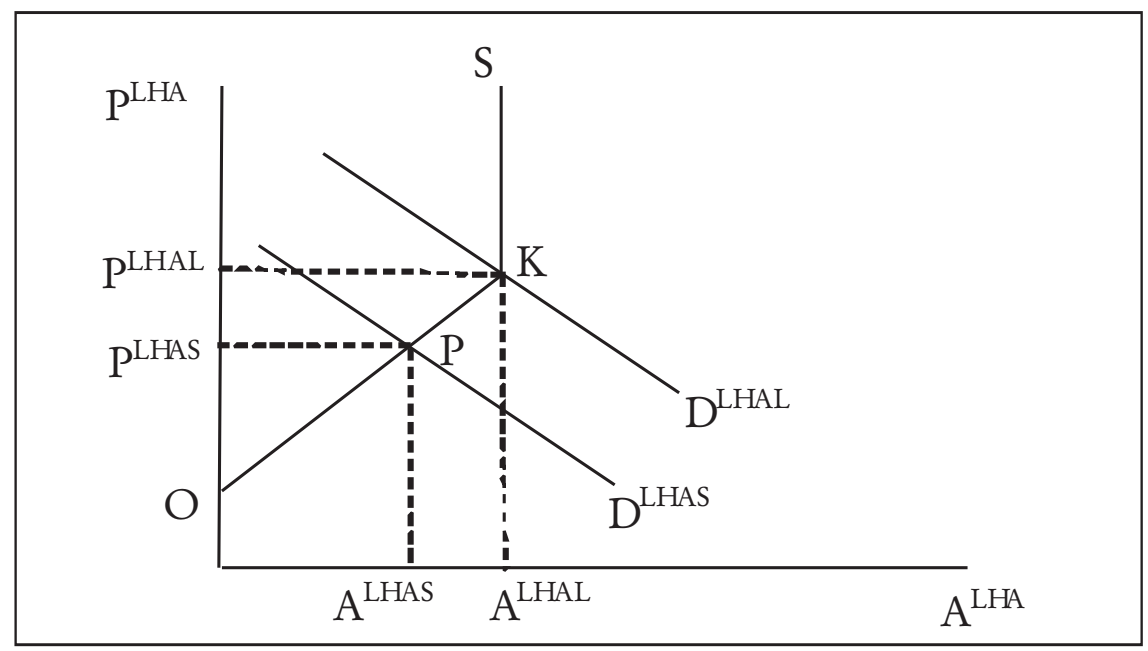

Gambar 3. Keseimbangan pasar lahan hutan alam

Figure 3. Natural forest land market equilibrium

\section{Analisis degradasi hutan alam}

Degradasi hutan alam dapat didefinisikan dengan beragam pengertian, bergantung pada kepentingan. Bagi kalangan yang lebih menekankan pada fungsi produksi dibanding fungsi yang lain, akan cenderung mendefinisikan degradasi hutan sebagai kondisi hutan yang mengalami perubahan, sehingga fungsi produksi menjadi terganggu atau musnah. Sebagai contoh, hutan alam yang telah mengalami penebangan dapat dinyatakan sebagai hutan yang terdegradasi jika kondisi hutannya tidak layak lagi secara finansial dimanfaatkan (tanpa upaya penanaman dan penataan ulang struktur tegakannya menuju kelestarian hasil). Bagi kalangan yang lebih menekankan pada fungsi penyerap $\mathrm{CO}_{2}$ di atmosfer, akan cenderung mendefinisikan degradasi hutan sebagai kondisi hutan yang mengalami perubahan, sehingga fungsi penyerap $\mathrm{CO}_{2}$ di atmosfer menjadi terganggu atau musnah. Intergovernmental Panel on Climate Changes (IPPC), termasuk kalangan yang lebih menekankan pada fungsi hutan sebagai penyerap $\mathrm{CO}_{2}$. Dalam hal ini, degradasi hutan didefinisikan sebagai "kehilangan setidaknya Y\% stok karbon (dan nilai hutan) dalam jangka waktu lama (selama setidaknya $\mathrm{X}$ tahun) sejak waktu $\mathrm{T}$ yang disebabkan kegiatan manusia dan tidak dianggap sebagai deforestasi (IPCC 2003a dalam Murdiyarso et al 2008).

Wounder dan Verbist (2003) menyatakan bahwa proses degradasi hutan merupakan suatu proses dengan kategori intervensi yang secara signifikan mengubah kualitas hutan, struktur dan fungsi hutan, tetapi tidak mengubah status arealnya sebagai hutan menurut kriteria FAO. Termasuk ke dalam kategori degradasi hutan adalah tebang pilih, yang menurunkan tutupan tajuk hutan, tetapi biasanya tidak di bawah $10 \%$ minimum threshold. Menurut Wounder dan Verbist (2003), proses degradasi hutan sering dikaitkan dengan uang tunai melalui over-harvesting dari beragam hasil hutan untuk memperoleh manfaat ekonomi sekarang dan kurang mempertimbangkan masa datang. Pengertian degradasi hutan yang lengkap dapat didasarkan pada fungsi ekosistem. Fungsi ekosistem dapat dipisahkan ke dalam fungsi rantai makanan flora dan fauna, fungsi tata air (hidroorologi), dan fungsi jasa lingkungan (iklim mikro, penyerap $\mathrm{CO}_{2}$, dan keindahan). Dengan pengertian ini, degradasi hutan dapat didefinisikan sebagai kondisi hutan yang mengalami perubahan, sehingga fungsi ekosistem hutan menjadi terganggu atau musnah. 
Apapun pengertian degradasi hutan yang diberikan, persoalannya adalah bagaimana menetapkan ambang batas kondisi yang dapat dikategorikan sebagai kondisi yang terdegradasi. Menyadari penetapan ambang batas tersebut adalah sulit, pengertian degradasi hutan dalam penelitian ini lebih membatasi diri pada pengertian dan analisis degradasi hutan yang terjadi pada hutan alam produksi, bukan pada hutan tanaman, hutan lindung atau hutan konservasi. Degradasi hutan diartikan sebagai perubahan kondisi hutan alam akibat penebangan yang melebihi potensi produksi lestari. Dengan pengertian ini, areal bekas penebangan (LOA) dikategorikan sebagai hutan terdegradasi, selama best practice pengelolaan hutan alam produksi umumnya belum terwujud di lapangan (Ismanto, 2010). Dalam kasus terdapat LOA yang masih produktif diinterpreasikan sebagai suatu kondisi LOA yang areal hutannya belum seluruhnya dilakukan penebangan, sehingga terdapat bagian hutan yang masih produktif.

Dengan pengertian tersebut, laju degradasi dianalisis seperti laju deforestasi menggunakan teori permintaan input produksi. Dalam hal ini, permintaan input LHA dipandang sebagai permintaan input untuk memproduksi output: kayu hutan alam. Permintaan input LHA dipengaruhi oleh harganya, harga output (kayu hutan alam), harga output turunan (kayu lapis, kayu gergajian, pulp), dan faktor-faktor yang lain, seperti harga input selain LHA dan kebijakan pemerintah. Seperti dalam analisis deforestasi hutan alam, suku bunga merupakan harga input selain LHA yang menjadi fokus kajian. Kebijakan makroekonomi dan faktor eksternal ekonomi akan mempengaruhi suku bunga, dan perubahan suku bunga secara langsung akan mempengaruhi laju degradasi hutan alam melalui pengaruhnya terhadap permintaan input LHA. Perubahan faktorfaktor yang mempengaruhi permintaan input LHA akan menggeser kurva permintaan LHA $\left(D^{\text {LHAS }}\right)$ ke kiri atau ke kanan. Dalam hal ini, pergeseran kurva $\mathrm{D}^{\mathrm{LHAS}}$ ke kiri menunjukkan terjadi penurunan laju degradasi dan sebaliknya pergeseran kurva $\mathrm{D}^{\text {LHAS }}$ ke kanan menunjukkan terjadi peningkatan laju degradasi. Fenomena terjadinya degradasi hutan alam didasarkan pada prinsip pengelolaan hutan bahwa penebangan hutan tidak boleh melebihi potensi produksi lestari, yang pada Gambar 4 ditunjukkan oleh tingkat produksi yang melebihi $\mathrm{Q}^{\mathrm{KL} 2}$ pada tingkat harga $\mathrm{P}^{\mathrm{KL} 2}$.

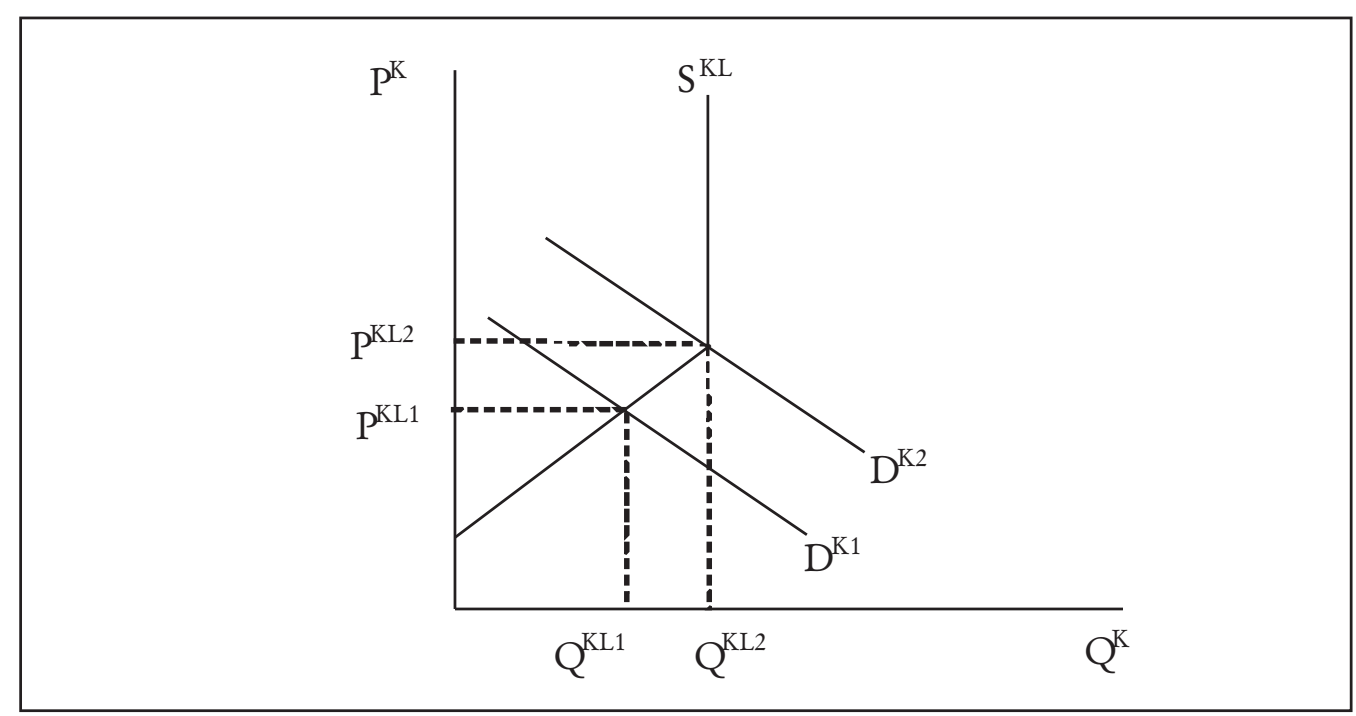

Gambar 4. Keseimbangan pasar kayu hutan alam

Figure 4. Natural forest timber market equilibrium 


\section{METODE PENELITIAN}

\section{A. Piranti Analisis}

Dampak kebijakan makroekonomi dan faktor eksternal ekonomi terhadap laju deforestasi dan degradasi hutan alam dianalisis menggunakan model ekonometrika persamaan simultan. Struktur modelnya terdiri dari tiga blok, yaitu: (1) blok makroekonomi, (2) blok deforestasi, dan (3) blok degradasi hutan (Lampiran 1 dan Lampiran 2). Model diduga menggunakan metode 2SLS (Two-Stage Least Squares). Pengaruh bersama-sama dari peubah penjelas dari setiap persamaan dalam model diuji menggunakan uji $\mathrm{F}$, dan pengaruh individual peubah penjelasnya diuji menggunakan uji t. Untuk memastikan model terbebas dari korelasi serial diuji menggunakan Durbin-Watson Statistics dan Durbin- $h$. Validasi model dilakukan untuk mengetahui seberapa jauh model (secara utuh) mampu menelusur kembali data dengan baik sehingga model menjadi valid digunakan untuk simulasi historis atau peramalan (forecasting).

\section{B. Kebijakan Makroekonomi dan Faktor Eksternal Ekonomi}

Kebijakan makroekonomi yang dianalisis terdiri dari: (1) kebijakan moneter yakni penawaran uang, dan (2) kebijakan fiskal yakni pengeluaran pemerintah. Faktor eksternal ekonomi yang dianalisis terdiri dari: (1) suku bunga Amerika Serikat, dan (2) harga minyak mentah dunia. Perubahan kebijakan moneter didasarkan pada data pertumbuhan uang (M2) periode 1980-2008 yang rataan per tahun sebesar $23.12 \%$. Sedangkan perubahan kebijakan fiskal didasarkan pada pertumbuhan total pengeluaran pemerintah periode 1980 2008 yang rataan per tahun sebesar 17.96\%. Perubahan suku bunga dunia didasarkan pada pertumbuhan suku bunga rujukan Amerika Serikat periode 1980-2008 yang rataan per tahun sebesar 5.0\%. Sedangkan perubahan harga minyak mentah dunia didasarkan pada pertumbuhan harga minyak mentah periode 1980-2008 yang rataan per tahun sebesar $7.0 \%$.

\section{Data}

Data yang digunakan adalah data deret waktu 1980-2008. Data degradasi hutan menggunakan data laju perubahan luas areal HPH (1000 ha), sedangkan data deforestasi menggunakan laju perubahan luas areal HTI, tanaman sawit, karet, dan padi (1000 ha). Data deforestasi dan degradasi hutan alam dikumpulkan dari publikasi Kementerian Pertanian, dan Kementerian Kehutanan. Data penawaran uang M2 dikumpulkan dari publikasi Bank Indonesia, sedangkan data pengeluaran pemerintah dari publikasi Kementerian Keuangan. Data harga minyak mentah dunia dikumpulkan dari publikasi International Energy Administration (IEA), sedangkan data suku bunga rujukan Amerika Serikat dari Bureau of Economic Analysis, US Government.

\section{HASIL DAN PEMBAHASAN}

\section{A. Dampak terhadap Perekonomian}

Hasil analisis dampak kebijakan makroekonomi dan faktor eksternal ekonomi terhadap perekonomian disajikan berturutturut pada Tabel 1 dan Tabel 2. Tabel 1 menyajikan dampak kebijakan makroekonomi terhadap perekonomian, yang meliputi: (1) kebijakan moneter yakni penawaran uang, dan (2) kebijakan fiskal yakni pengeluaran pemerintah. Sedangkan Tabel 2 menyajikan dampak faktor eksternal ekonomi terhadap perekonomian, yang meliputi: (1) suku bunga rujukan Amerika Serikat, dan (2) harga minyak mentah dunia. 
Tabel 1. Dampak kebijakan makroekonomi terhadap produk domestik bruto dan suku bunga domestik Table 1. Macroeconomic policy impact on gross domestic product and domestic interest rate

\begin{tabular}{|c|c|c|c|c|}
\hline \multirow[b]{2}{*}{ No. } & \multirow[b]{2}{*}{$\begin{array}{l}\text { Peubah } \\
\text { (Variable) }\end{array}$} & \multirow[b]{2}{*}{$\begin{array}{c}\text { Nilai d asar } \\
\text { (Baseline) } \\
(\%)\end{array}$} & \multicolumn{2}{|c|}{$\begin{array}{c}\text { Skenario kebijakan makroekonomi } \\
\text { (Macroeconomic policy scenario) }\end{array}$} \\
\hline & & & $\begin{array}{c}\text { MS Naik (Increase by) } \\
(23.12 \%) \\
\text { Dampak (Impact) } \\
(\%) \\
\end{array}$ & $\begin{array}{c}\text { GS Naik (Increase by) } \\
(17.96 \%) \\
\text { Dampak (Impact) } \\
(\%)\end{array}$ \\
\hline 1. & $\begin{array}{l}\text { Suku bunga domestik } \\
\text { (Domestic interest rate) }\end{array}$ & $\begin{array}{c}14,0 \\
(\text { miliar } \mathrm{Rp})\end{array}$ & $-10,47$ & 3.03 \\
\hline 2. & $\begin{array}{l}\text { Produk domestik bruto } \\
\text { (Gross domestic product) }\end{array}$ & 1200841,0 & 2,29 & 1,39 \\
\hline
\end{tabular}

Keterangan (Remark): MS: Penawaran uang (Money supply); GS: Pengeluaran pemerintah (Government spending)

Hasil analisis kebijakan moneter menunjukkan bahwa dengan asumsi faktorfaktor lain tidak berubah, dari Tabel 1 diketahui bahwa ekspansi moneter sebesar $23,12 \%$ dapat diharapkan akan menurunkan suku bunga domestik sebesar $10,47 \%$, dan meningkatkan PDB sebesar 2,29\%. Sedangkan hasil analisis kebijakan fiskal menunjukkan bahwa dengan asumsi faktor-faktor lain tidak berubah, dari Tabel 1 diketahui bahwa ekspansi fiskal sebesar $17,96 \%$ dapat diharapkan akan menaikkan suku bunga domestik sebesar 3,03\% dan PDB sebesar $1,39 \%$. Dengan demikian, sesuai teori, ekspansi moneter dapat diharapkan akan meningkatkan PDB dan menurunkan suku bunga domestik, sedangkan ekspansi fiskal akan meningkatkan PDB dan suku bunga domestik.

Tabel 2. Dampak faktor eksternal ekonomi terhadap produk domestik bruto dan suku bunga domestik Table 2. Economic external factor impact on gross domestic product and domestic interest rate

\begin{tabular}{|c|c|c|c|c|}
\hline \multirow[b]{2}{*}{ No. } & \multirow[b]{2}{*}{$\begin{array}{l}\text { Peubah } \\
\text { (Variable) }\end{array}$} & \multirow[b]{2}{*}{$\begin{array}{l}\text { Nilai dasar } \\
\text { (Baseline) }\end{array}$} & \multicolumn{2}{|c|}{$\begin{array}{l}\text { Skenario faktor eksternal ekonomi (Economic } \\
\text { external factor scenario) }\end{array}$} \\
\hline & & & $\begin{array}{c}\text { FFR Naik (Increase by) } \\
(5.0 \%) \\
\text { Dampak (Impact) } \\
(\%) \\
\end{array}$ & $\begin{array}{c}\text { WOP Naik (Increase by) } \\
\text { (7.0\%) } \\
\text { Dampak (Impact) } \\
(\%)\end{array}$ \\
\hline 1. & $\begin{array}{l}\text { Suku bunga domestik } \\
\text { (Domestic interest rate) }\end{array}$ & 14,0 & 0,09 & $-0,01$ \\
\hline 2. & $\begin{array}{l}\text { Produk domestik bruto } \\
\text { (Gross domestic product) }\end{array}$ & $\begin{array}{l}\text { (miliar Rp) } \\
1200841,0\end{array}$ & 0,04 & $-0,00$ \\
\hline
\end{tabular}

Keterangan (Remark): FFR: Suku Bunga Amerika Serikat (Federal Fund Rate); WOP: Harga Minyak Mentah Dunia (World Oil Price) 
Hasil analisis faktor eksternal ekonomi yakni kenaikan suku bunga rujukan Amerika Serikat menunjukkan bahwa dengan asumsi faktor-faktor lain tidak berubah, dari Tabel 2 diketahui bahwa kenaikan suku bunga Amerika Serikat sebesar 5,0\% dapat diharapkan akan meningkatkan PDB sebesar $0,04 \%$ dan suku bunga domestik sebesar $0,09 \%$. Sedangkan hasil analisis faktor eksternal ekonomi yakni harga minyak mentah dunia, dari Tabel 2 diketahui bahwa kenaikan harga minyak mentah dunia sebesar $7,0 \%$ dapat diharapkan akan menurunkan PDB meskipun relatif kecil sebesar 0,00\% (Rp 1.200.841 miliar menjadi Rp 1.200.804 miliar) dan suku bunga domestik sebesar 0,01\%. Net effect kenaikan harga minyak mentah dunia terhadap PDB cenderung bernilai negatif atau cenderung menurunkan PDB dan suku bunga domestik. Dengan demikian, sesuai hipotesis, kenaikan suku bunga rujukan Amerika Serikat cenderung meningkatkan PDB dan suku bunga domestik, dan sebaliknya kenaikan harga minyak mentah dunia cenderung menurunkan PDB dan suku bunga domestik.

\section{B. Dampak terhadap Laju Deforestasi dan Degradasi Hutan Alam}

Hasil analisis dampak kebijakan makroekonomi dan faktor eksternal ekonomi terhadap laju deforestasi dan degradasi hutan alam disajikan berturut-turut pada Tabel 3 dan Tabel 4. Table 3 menyajikan dampak kebijakan makroekonomi terhadap laju deforestasi dan degradasi hutan alam, yang meliputi: (1) kebijakan moneter yakni penawaran uang, dan (2) kebijakan fiskal yakni pengeluaran pemerintah. Sedangkan Tabel 4 menyajikan dampak faktor eksternal ekonomi terhadap laju deforestasi dan degradasi hutan alam, yang meliputi: (1) suku bunga Amerika Serikat, dan (2) harga minyak mentah dunia.

Hasil analisis kebijakan moneter menunjukkan bahwa dengan asumsi faktorfaktor lain tidak berubah, dari Tabel 3 diketahui bahwa ekspansi moneter sebesar $23,12 \%$, sesuai hipotesis, dapat diharapkan akan meningkatkan laju deforestasi sebesar 9,08\%, dan menurunkan laju degradasi sebesar $109,73 \%{ }^{11}$. Namun pada Tabel 3 juga diketahui bahwa hipotesis tersebut tidak terbukti dalam kasus laju deforestasi untuk areal HTI dan areal tanaman sawit. Dari model yang digunakan diketahui bahwa penyimpangan hipotesis tersebut disebabkan oleh pengaruh penurunan suku bunga (akibat peningkatan penawaran uang), yang secara langsung mempengaruhui laju deforestasi lebih kecil dibanding pengaruh penurunan suku bunga (akibat peningkatan penawaran uang), yang secara tidak langsung mempengaruhi laju deforestasi melalui pengaruhnya terhadap permintaan dan penawaran serta harga komoditas.

Dalam kasus laju deforestasi untuk areal HTI, harga komoditas yang secara tidak langsung dipengaruhi oleh suku bunga dan mempengaruhi secara langsung laju deforestasi adalah harga kayu HTI dan harga kayu hutan alam. Di satu sisi, penurunan suku bunga secara langsung menaikkan penawaran kayu HTI (5,79\%) dan penawaran kayu hutan alam (2,10\% untuk kayu legal dan 2,71\% untuk kayu ilegal). Kenaikan penawaran kayu hutan alam menurunkan harga kayu hutan alam $(2,84 \%)$, sedangkan kenaikan penawaran kayu HTI akan menurunkan harga kayu HTI. Selain dipengaruhi oleh penawarannya, harga kayu HTI juga dipengaruhi oleh harga kayu hutan alam, dan pengaruh bersih keduanya menyebabkan harga kayu HTI meningkat ${ }^{12}$

\footnotetext{
${ }^{11}$ Dari -801.0 ribu ha menurun menjadi 77.933 ribu ha di mana tanda negatif menunjukkan areal yang terdegradasi dan tanda positif menunjukkan penambahan areal yang tidak terdegradasi.

${ }^{12}$ Hasil analisis empiris menunjukkan bahwa elastisitas penawaran kayu HTI dari harga kayu HTI $(-0,008)$ lebih rendah dibanding elastisitas harga kayu hutan alam dari harga kayu HTI $(-0,024)$ dan dalam model secara simultan menyebabkan harga kayu HTI meningkat $(0,17 \%)$.
} 
(0,17\%), yang menyebabkan laju deforestasi menurun ${ }^{13}$. Di sisi lain, penurunan suku bunga secara langsung dapat diharapkan akan meningkatkan laju deforestasi $1^{14}$, namun secara simultan karena pengaruh suku bunga lebih kecil dibanding pengaruh kenaikan harga kayu HTI menyebabkan laju deforestasi untuk areal HTI menurun (-0,03\%). Dengan demikian, penurunan suku bunga (secara langsung dan tidak langsung) dapat diharapkan akan meningkatkan laju deforestasi untuk areal HTI hanya jika secara simultan pengaruh suku bunga secara langsung lebih tinggi dibanding pengaruh suku bunga secara tidak langsung melalui pengaruhnya terhadap harga kayu HTI dan harga kayu hutan alam.

Dalam kasus laju deforestasi untuk areal tanaman sawit, harga komoditas yang dipengaruhi secara tidak langsung oleh suku bunga dan secara langsung mempengaruhi laju deforestasi adalah harga buah sawit, harga kayu HTI dan harga kayu hutan alam. Di satu sisi, penurunan suku bunga secara langsung, yang diperkuat oleh kenaikan PDB, meningkatkan permintaan buah sawit $(8,16 \%)$, sehingga harga buah sawit meningkat (1,39\%). Selain itu, penurunan suku bunga secara langsung juga menaikkan penawaran kayu HTI $(5,79 \%)$ dan kayu hutan alam $(2,10 \%$ untuk kayu legal dan $2,71 \%$ untuk kayu ilegal). Kenaikan penawaran kayu hutan alam menurunkan

\footnotetext{
${ }^{13}$ Elastisitas harga kayu HTI dari laju deforestasi untuk areal HTI adalah 7,90, yang berarti kenaikan harga kayu HTI sebesar $1 \%$ dapat diharapkan akan menurunkan laju deforestasi untuk areal HTI sebesar $7,90 \%$, ceteris paribus.

${ }^{14}$ Dalam kasus laju deforestasi untuk areal HTI, peubah suku bunga diproxy menggunakan angka perbedaan antara suku bunga tahun sekarang $\left(R_{t}\right)$ dan dua tahun sebelumnya $\left(R_{t-2}\right),\left(\Delta R=R_{t}-R_{t 2}\right)$, sehingga ada dua kemungkinan atas tanda elastisitas yang diperoleh, yaitu negatif atau positif. Tanda negatif menunjukkan bahwa $R_{t}>$ $R_{t 2}$, sehingga penurunan $\Delta R$ menunjukkan penurunan $R$ dan kenaikan $\Delta \mathrm{R}$ menunjukkan kenaikan $\mathrm{R}$, sedangkan tanda positif menunjukkan bahwa $R_{t}<R_{t-2}$, sehingga penurunan $\Delta R$ menunjukkan kenaikan $\mathrm{R}$ dan kenaikan $\Delta \mathrm{R}$ menunjukkan penurunan R. Hasil analisis empiris menunjukkan bahwa elastisitas suku bunga $(\Delta \mathrm{R})$ dari laju deforestasi untuk areal HTI bertanda positif $(0,03)$, sehingga kenaikan $\Delta \mathrm{R}$ atau penurunan suku bunga dapat diharapkan akan meningkatkan laju deforestasi untuk areal HTI, dan sebaliknya.
}

harga kayu hutan alam (2,84\%), sedangkan kenaikan penawaran kayu HTI akan menurunkan harga kayu HTI. Namun karena harga kayu hutan alam mempengaruhi secara negatif harga kayu HTI, pengaruh bersih keduanya menyebabkan harga kayu HTI meningkat $(0,17 \%)$ (catatan kaki 13$)$. Di sisi lain, penurunan suku bunga secara langsung meningkatkan laju deforestasi untuk areal tanaman sawit ${ }^{15}$, namun secara simultan pengaruhnya lebih kecil dibanding penurunannya karena pengaruh penurunan harga kayu hutan alam ${ }^{16}$ (pengaruh simbiose kepentingan antara kebutuhan biaya kebun dan penghasilan penjualan kayu), kenaikan harga buah sawit ${ }^{17}$ (pengaruh harga input produksi minyak sawit) dan harga kayu HTI ${ }^{18}$, sehingga laju deforestasi untuk areal tanaman sawit menurun (-1.83\%). Dengan demikian, penurunan suku bunga (akibat ekspansi moneter) akan meningkatkan laju deforestasi untuk areal tanaman sawit hanya jika secara simultan pengaruh penurunan suku bunga secara langsung lebih tinggi dibanding pengaruh penurunan suku bunga secara tidak langsung melalui pengaruhnya terhadap harga buah sawit, harga kayu HTI dan harga kayu hutan alam.

Hasil analisis kebijakan fiskal menunjukkan bahwa dengan asumsi faktor-faktor lain tidak berubah, dari Tabel 3 diketahui bahwa

\footnotetext{
Dalam kasus laju deforestasi untuk tanaman sawit, peubah suku bunga yang berpengaruh adalah suku bunga 3 tahun sebelumnya, $\mathrm{R}_{\mathrm{t}-3}$, dan hasil analisis empiris memperoleh elastisitas suku bunga $\left(\mathrm{R}_{\mathrm{t}-3}\right)$ dari laju deforestasi untuk areal tanaman sawit sebesar $-0,19$, yang berarti bahwa penurunan suku bunga sebesar $1 \%$ dapat diharapkan akan meningkatkan laju deforestasi untuk areal tanaman sawit sebesar 0,19\%.

${ }^{16}$ Elastisitas harga kayu hutan alam dari laju deforestasi untuk areal tanaman sawit adalah 2,83, yang berarti penurunan harga kayu hutan alam sebesar $1 \%$ dapat diharapkan akan menurunkan laju deforestasi untuk areal tanaman sawit sebesar 2,83\%.

${ }^{17}$ Elastisitas harga buah sawit dari laju deforestasi untuk areal tanaman sawit adalah -0,84, yang berarti kenaikan harga buah sawit sebesar $1 \%$ dapat diharapkan akan menurunkan laju deforestasi untuk areal tanaman sawit sebesar 0,84\%.

${ }^{18}$ Elastisitas harga kayu HTI dari laju deforestasi untuk areal tanaman sawit adalah -2,18, yang berarti kenaikan harga kayu HTI sebesar $1 \%$ dapat diharapkan akan menurunkan laju deforestasi untuk areal tanaman sawit sebesar $2,18 \%$.
} 
ekspansi fiskal sebesar 17,96\%, sesuai hipotesis, dapat diharapkan akan menurunkan laju deforestasi sebesar 3,27\% dan meningkatkan laju degradasi sebesar 31,74\%. Dari Tabel 3 diketahui bahwa penyimpangan hipotesis tidak terjadi seperti dalam kasus dampak kebijakan moneter. Hal ini menunjukkan bahwa pengaruh secara langsung kenaikan suku bunga (akibat ekspansi fiskal) terhadap laju deforestasi lebih tinggi dibanding pengaruh secara tidak langsung melalui pengaruhnya terhadap harga komoditas secara individual.

Dalam kasus laju deforestasi untuk areal HTI, harga komoditas yang dipengaruhi secara tidak langsung oleh suku bunga dan secara langsung mempengaruhi laju deforestasi adalah harga kayu HTI dan kayu hutan alam. Hasil analisis empiris menunjukkan bahwa kenaikan suku bunga menurunkan penawaran kayu HTI (1,64\%), dan penawaran kayu hutan alam (0,58\% kayu legal dan 0,77\% kayu ilegal). Penurunan penawaran kayu hutan alam menaikkan harga kayu hutan alam (0,78\%), sedangkan penurunan penawaran kayu HTI akan menaikkan harga kayu HTI, namun karena pengaruh secara negatif kenaikan harga kayu hutan alam, menyebabkan harga kayu HTI menurun (0,06\%) (catatan kaki 13). Penurunan harga kayu HTI menyebabkan laju deforestasi untuk areal HTI meningkat ${ }^{19}$, namun karena secara simultan pengaruh kenaikan suku bunga secara langsung lebih tinggi ${ }^{20}$ menyebabkan laju deforestasi menurun (0,17\%). Dalam kasus laju deforestasi untuk areal tanaman sawit, harga komoditas yang dipengaruhi secara tidak langsung oleh suku bunga dan secara langsung mem pengaruhi laju deforestasi adalah harga buah sawit, harga kayu HTI dan harga kayu hutan alam. Hasil analisis empiris menunjukkan bahwa kenaikan suku bunga menurunkan permintaan buah sawit, namun karena pengaruh PDB (Produk Domestik Bruto) lebih besar, menyebabkan permintaan buah sawit meningkat (1,95\%), sehingga harga buah sawit juga meningkat $(0,33 \%)$. Kenaikan suku bunga menurunkan penawaran kayu HTI $(1,64 \%)$, dan penawaran kayu hutan alam $(0,58 \%$ kayu legal dan $0,77 \%$ kayu ilegal). Penurunan penawaran kayu hutan alam menaikkan harga kayu hutan alam $(0,78 \%)$, sedangkan penurunan penawaran kayu HTI akan menaikkan harga kayu HTI, namun karena pengaruh secara negatif kenaikan harga kayu hutan alam, menyebabkan harga kayu HTI menurun (0,06\%). Kenaikan harga kayu hutan alam dan penurunan harga kayu HTI menyebabkan laju deforestasi meningkat, namun karena secara simultan pengaruh secara langsung kenaikan suku bunga dan kenaikan harga buah sawit lebih tinggi, menyebabkan laju deforestasi

\footnotetext{
${ }^{19}$ Elastisitas harga kayu HTI dari laju deforestasi untuk areal HTI adalah $-7,90$. Hal ini berarti bahwa dengan asumsi faktor-faktor lain tidak berubah, penurunan harga kayu HTI sebesar 0,06\% dapat diharapkan akan meningkatkan laju deforestasi untuk areal HTI sebesar $0,46 \%(0,06 \% * 7,90)$.
}

\footnotetext{
Dalam kasus deforestasi untuk areal HTI, telah dijelaskan bahwa pengaruh secara langsung suku bunga ditunjukkan oleh pengaruh peubah $\Delta R$. Hasil analisis empiris menunjukkan bahwa ekspansi fiskal sebesar $17,96 \%$ menyebabkan $\Delta \mathrm{R}$ menurun sebesar $44,44 \%$ (penurunan $\Delta \mathrm{R}$ menunjukkan kenaikan suku bunga), sehingga dengan asumsi faktor-faktor lain tidak berubah dan elastisitas $\Delta R$ dari laju deforestasi untuk areal HTI sebesar 0,03, maka penurunan $\Delta \mathrm{R}$ sebesar $44,44 \%$ dapat diharapkan akan menurunkan laju deforestasi untuk areal HTI sebesar 1,33\%. Secara simultan pengaruh suku bunga terhadap laju deforestasi untuk areal HTI lebih besar dibanding pengaruh kenaikan harga kayu HTI, sehingga laju deforestasi untuk areal HTI menurun.
} 
Tabel 3. Dampak kebijakan makroekonomi terhadap laju deforestasi dan degradasi hutan alam Table 3. Macroeconomic policy impact on natural forest degradation and deforestation rates

\begin{tabular}{|c|c|c|c|c|}
\hline \multirow{3}{*}{ No. } & \multirow{3}{*}{ Peubah (Variable) } & \multirow{3}{*}{$\begin{array}{r}\text { Nilai dasar } \\
\text { (Baseline) }\end{array}$} & \multicolumn{2}{|c|}{$\begin{array}{l}\text { Skenario kebijakan makroekonomi } \\
\text { (Macroeconomic policy scenario) }\end{array}$} \\
\hline & & & $\begin{array}{l}\text { MS Naik } \\
\text { (Increase by) } \\
(23.12 \%)\end{array}$ & $\begin{array}{l}\text { GS Naik } \\
\text { (Increase by } \\
(17.96 \%)\end{array}$ \\
\hline & & & $\begin{array}{c}\text { Dampak } \\
\text { (Impact) } \\
(\%) \\
\end{array}$ & $\begin{array}{c}\text { Dampak } \\
\text { (Impact) } \\
(\%) \\
\end{array}$ \\
\hline \multirow[t]{5}{*}{1.} & $\begin{array}{l}\text { Laju deforestasi hutan a lam } \\
\text { (Deforestation rate of } n \text { atural forest) }\end{array}$ & 754,6 & 9,08 & $-3,27$ \\
\hline & $\begin{array}{l}\text { a. Laju deforestasi untuk areal HTI } \\
\text { (Deforestat ion rate for timber e state } \\
\text { area) }\end{array}$ & 291,3 & $-0,03$ & $-0,17$ \\
\hline & $\begin{array}{l}\text { b. Laju deforestasi untuk areal } \\
\text { tanaman S awit (Deforestation rate } \\
\text { for palm oil plantation a rea) }\end{array}$ & 257,3 & $-1,83$ & $-0,04$ \\
\hline & $\begin{array}{l}\text { c. Laju deforestasi untuk areal } \\
\text { tanaman Karet (Deforestation rate } \\
\text { for rubber plantation area) }\end{array}$ & 38,6 & 35,70 & $-10,29$ \\
\hline & $\begin{array}{l}\text { d. Laju deforestasi untuk areal } \\
\text { tanaman Padi (Deforestation rate for } \\
\text { paddy field area) }\end{array}$ & 167,4 & 35,54 & $-12,01$ \\
\hline 2. & $\begin{array}{l}\text { Laju Degradasi Hutan Alam ( Natural } \\
\text { forest degradation r ate) }\end{array}$ & $-801,0 *$ & $-109,73$ & 31,74 \\
\hline
\end{tabular}

Keterangan(Remark): MS: Penawaran Uang (Money Supply); GS: Pengeluaran Pemerintah (Government Spending); *tanda negatif menunjukkan luas hutan yang terdegradasi (negativesign describes degraded forest area).

Hasil analisis faktor eksternal ekonomi yakni kenaikan suku bunga Amerika Serikat menunjukkan bahwa dengan asumsi faktorfaktor lain tidak berubah, dari Tabel 4 diketahui bahwa kenaikan suku bunga Amerika Serikat sebesar $5,0 \%$, sesuai hipotesis, dapat diharapkan akan menurunkan laju deforestasi sebesar $0,11 \%$ dan menaikkan laju degradasi sebesar $0,96 \%$. Namun dari Tabel 4 diketahui bahwa peningkatan suku bunga Amerika Serikat atau kenaikan suku bunga domestik menaikkan meskipun relatif kecil laju deforestasi untuk areal HTI $(0,03 \%)$ dan areal tanaman sawit $(0,00 \%)$. Penyimpangan hipotesis ini disebabkan oleh pengaruh secara langsung kenaikan suku bunga domestik terhadap laju deforestasi secara simultan lebih rendah dibanding pengaruh secara tidak langsung kenaikan suku bunga domestik melalui pengaruhnya terhadap harga komoditas yang dihasilkan. 
Tabel 4. Dampak faktor eksternal ekonomi terhadap laju deforestasi dan degradasi hutan alam Table 4. Economic external factor impact on natural forest degradation and deforestation rates

\begin{tabular}{|c|c|c|c|c|}
\hline \multirow{4}{*}{ No. } & \multirow{4}{*}{ Peubah (Variable) } & \multirow{3}{*}{$\begin{array}{r}\text { Nilai dasar } \\
\text { (Baseline) }\end{array}$} & \multicolumn{2}{|c|}{$\begin{array}{l}\text { Skenario faktor eksternal ekonomi } \\
\text { (Economic external factor scenario) }\end{array}$} \\
\hline & & & $\begin{array}{c}\text { FFR Naik } \\
\text { (Increase by) } \\
(5.0 \%)\end{array}$ & $\begin{array}{c}\text { WOP Naik } \\
\text { (Increase by) } \\
(7.0 \%)\end{array}$ \\
\hline & & & Dampak (Impact) & Dampak \\
\hline & & & $(\%)$ & $(\%)$ \\
\hline \multirow[t]{5}{*}{1.} & $\begin{array}{l}\text { Laju Deforestasi Hutan Alam } \\
\text { (Deforestation Rate of Natural } \\
\text { Forest) }\end{array}$ & 754,6 & -0.11 & 0.00 \\
\hline & $\begin{array}{l}\text { a. Laju Deforestasi untuk Areal } \\
\text { HTI (Deforestation Rate for } \\
\text { Timber Estate Area) }\end{array}$ & 291,3 & 0,03 & 0,00 \\
\hline & $\begin{array}{l}\text { b. Laju Deforestasi untuk Areal } \\
\text { Tanaman Sawit ( Deforestation } \\
\text { Rate for Palm Oil Plantation } \\
\text { Area) }\end{array}$ & 257,3 & 0,00 & 0,00 \\
\hline & $\begin{array}{l}\text { c. Laju deforestasi untuk Areal } \\
\text { Tanaman Karet (Deforestation } \\
\text { Rate for Rubber Plantation } \\
\text { Area) }\end{array}$ & 38,6 & $-0,32$ & 0,03 \\
\hline & $\begin{array}{l}\text { d. Laju deforestasi untuk Areal } \\
\text { Tanaman Padi (Deforestation } \\
\text { Rate for Paddy Field Area) }\end{array}$ & 167,4 & $-0,36$ & 0,06 \\
\hline 2. & $\begin{array}{l}\text { Laju Degradasi Hutan Alam } \\
\text { (Natural Forest Degradation Rate) }\end{array}$ & $-801,0 *$ & 0,96 & $-0,10$ \\
\hline
\end{tabular}

Dalam kasus laju deforestasi untuk areal HTI, telah diterangkan bahwa harga komoditas yang dipengaruhi secara tidak langsung oleh suku bunga dan secara langsung mempengaruhi laju deforestasi adalah harga kayu HTI dan kayu hutan alam. Hasil analisis empiris menunjukkan bahwa kenaikan suku bunga domestik (akibat kenaikan suku bunga Amerika Serikat) secara langsung menurunkan penawaran kayu HTI $(0,05 \%)$ dan penawaran kayu hutan alam $(0,03 \%$ kayu ilegal dan $0,02 \%$ kayu legal). Penurunan penawaran kayu hutan alam menaikkan harga kayu hutan alam
$(0,03 \%)$, sedangkan penurunan penawaran kayu HTI seharusnya meningkatkan harga kayu HTI, tetapi karena pengaruh secara negatif oleh kenaikan harga kayu hutan alam menyebabkan harga kayu HTI cenderung tidak berubah $(0,00 \%)$. Di sisi lain, kenaikan suku bunga secara langsung akan menurunkan laju deforestasi, namun karena secara simultan pengaruh harga kayu HTI lebih tinggi dibanding pengaruh kenaikan suku bunga menyebabkan laju deforestasi meningkat $(0,03 \%)$. Dengan demikian, pengaruh kenaikan suku bunga (akibat kenaikan suku 
bunga Amerika Serikat) dapat diharapkan akan menurunkan laju deforestasi hanya jika secara simultan pengaruh suku bunga secara langsung lebih tinggi dibanding pengaruh secara tidak langsung.

Dalam kasus laju deforestasi untuk areal tanaman sawit, kenaikan suku bunga domestik akan menurunkan permintaan buah sawit, namun karena pengaruh PDB lebih besar menyebabkan permintaan buah sawit meningkat $(0,06 \%)$, sehingga harga buah sawit juga meningkat $(0,03 \%)$. Selain itu, kenaikan suku bunga domestik juga menurunkan penawaran kayu HTI $(0,05 \%)$ dan kayu hutan alam $(0,03 \%$ kayu ilegal dan 0,02\% kayu legal). Penurunan penawaran kayu hutan alam menaikkan harganya $(0,03 \%)$, sedangkan penurunan penawaran kayu HTI akan menaikkan harganya namun karena pengaruh secara negatif kenaikan harga kayu hutan alam secara simultan menyebabkan harga kayu HTI cenderung tidak berubah (0,00\%). Selanjutnya, kenaikan suku bunga dan harga buah sawit secara langsung akan menurunkan laju deforestasi, sedangkan kenaikan harga kayu hutan alam akan meningkatkan laju deforestasi. Hasil analisis empiris menunjukkan bahwa pengaruh secara langsung suku bunga domestik dan harga buah sawit serta pengaruh harga kayu HTI dan kayu hutan alam terhadap laju deforestasi untuk areal tanaman sawit secara simultan saling menetralkan, sehingga laju deforestasi tidak berubah (0,00\%). Dengan demikian seperti dalam kasus HTI, pengaruh kenaikan suku bunga (akibat kenaikan suku bunga rujukan Amerika Serikat) dapat diharapkan akan menurunkan laju deforestasi hanya jika pengaruhnya secara langsung terhadap laju deforestasi secara simultan lebih tinggi dibanding pengaruhnya secara tidak langsung.

Hasil analisis faktor eksternal ekonomi yakni kenaikan harga minyak mentah dunia menunjukkan bahwa dengan asumsi faktorfaktor lain tidak berubah, dari Tabel 4 diketahui bahwa kenaikan harga minyak mentah dunia sebesar 7,0\% tidak cukup besar dapat menimbulkan perubahan laju deforestasi $(0,00 \%)$, sebaliknya dapat menurunkan laju degradasi $(0,10 \%)$. Dengan demikian, perubahan laju deforestasi relatif kurang sensitif terhadap perubahan harga minyak mentah dunia dibanding perubahan laju degradasi. Lebih spesifik lagi, dari Tabel 4 diketahui bahwa kenaikan harga minyak mentah sebesar 7,0\% tidak cukup besar dapat menimbulkan perubahan terhadap laju deforestasi untuk areal HTI $(0,00 \%)$ dan areal tanaman sawit $(0,00 \%)$, sebaliknya dapat meningkatkan laju deforestasi untuk areal tanaman karet $(0,03 \%)$ dan tanaman padi $(0,06 \%)$. Dengan demikian, laju deforestasi untuk areal HTI dan tanaman sawit relatif kurang sensitif terhadap perubahan harga minyak mentah dunia dibanding laju deforestasi untuk areal tanaman karet dan padi.

\section{KESIMPULAN DAN SARAN}

\section{A. Kesimpulan}

1. Dampak kebijakan makroekonomi dan faktor eksternal ekonomi terhadap laju deforestasi dan degradasi hutan alam dapat dikontruksi ke dalam bentuk model dengan menetapkan suku bunga sebagai suatu saluran transmisi kebijakan dan faktor eksternal ekonomi, yang mempengaruhi laju deforestasi dan degradasi hutan alam. Dengan pendekatan tersebut, model yang digunakan memberikan hasil estimasi dampak yang konsisten.

2. Kebijakan makroekonomi, yaitu ekspansi moneter menurunkan dan ekspansi fiskal menaikkan suku bunga. Faktor eksternal ekonomi, yaitu kenaikan suku bunga rujukan Amerika Serikat cenderung menaikkan dan kenaikan harga minyak mentah dunia cenderung menurunkan suku bunga. Penurunan suku bunga cenderung 
menaikkan laju deforestasi dan menurunkan laju degradasi, sedangkan kenaikan suku bunga cenderung menurunkan laju deforestasi dan menaikkan laju degradasi.

3. Berkaitan dengan kebijakan makroekonomi, model memprediksi kebijakan ekspansi moneter sebesar 23,12\% dapat diharapkan akan meningkatkan laju deforestasi (hutan alam) sebesar 9,08\% (dari nilai dasar sebesar 754,6 ribu ha), dan menurunkan laju degradasi hutan alam sebesar 109,73\% (dari nilai dasar sebesar 801,0 ribu ha menjadi 77,9 ribu ha). Dengan nilai dasar yang sama, ekspansi fiskal sebesar $17,96 \%$ dapat diharapkan akan menurunkan laju deforestasi sebesar 3,27\%, dan meningkatkan laju degradasi sebesar $31,74 \%$.

4. Berkaitan dengan faktor ekstrnal ekonomi, model memprediksi kenaikan suku bunga Amerika Serikat sebesar 5,0\% dapat diharapkan akan menurunkan laju deforestasi (hutan alam) sebesar 0,11\% (dari nilai dasar sebesar 754,6 ribu ha), dan menaikkan laju degradasi hutan alam sebesar $0,96 \%$ (dari nilai dasar sebesar $-801,0$ ribu ha). Dengan nilai dasar yang sama, kenaikan harga minyak mentah dunia sebesar $7,0 \%$ belum cukup tinggi dapat menaikkan laju deforestasi, tetapi dapat diharapkan akan menurunkan laju degradasi sebesar $0,10 \%$.

\section{B. Saran}

1. Hasil analisis empiris menunjukkan bahwa saluran suku bunga merupakan saluran transmisi kebijakan makroekonomi dan faktor eksternal ekonomi yang signifikan dalam mempengaruhi besaran deforestasi dan degradasi hutan alam dan karenanya dapat digunakan sebagai salah satu instrumen kebijakan insentifdisinsentif yang efektif untuk mengendalikan laju deforestasi dan degradasi hutan alam, yang dapat diterapkan antara lain untuk mewujudkan target pengurangan emisi $\mathrm{CO}_{2}$ sebesar $14 \%$.

2. Penerapan instrumen insentif-disinsentif suku bunga tersebut dapat diarahkan untuk mencegah penebangan hutan secara berlebihan melalui perbaikan kinerja pengelolaan hutan alam produksi atau menurunkan laju degradasi hutan melalui peningkatan produktivitas hutan, di samping dapat juga diterapkan untuk mengendalikan ekspansi areal konversi hutan alam yang berlebihan melalui peningkatan produktivitas lahan, terutama areal tanaman pangan, tanaman karet, tanaman sawit dan HTI.

\section{DAFTAR PUSTAKA}

Alimov, B.S. 2002. Effects of International Trade and Corruption on Tropical Deforestation. PhD Dissertation, Univ. of Connecticut. UMI, Ann Arbor.

Contreras-Hermosilla, A., R. Doornbosch and M. Lodge. 2007. The Economics of Illegal Logging and Associated Trade. Round Table on Sustainable Development, OECD, Paris.

FAO. 2005. Global Forest Resources Assessment 2005. Progress Towards Sustainable Forest Management. FAO, Rome.

FAO 2000. FRA 2000. On definitions of forest and forest change. Rome, Food and Agricultural Organization of the United Nations, Rome.

Ismanto, A.D. 2010. Permasalahan Institusi Pengelolaan dan Pemanfaatan Hutan Alam Produksi. Disertasi Doktor. Sekolah Pascasarjana IPB, Bogor. 
Ireland, P.N. 2005. The Monetary Transmission Mechanism. Working Paper in Economics, Boston College, Boston.

Kaimovitz, D. and Angelsen, A. 1998. Economic Model of Tropical Deforestation: A Review. CIFOR, Bogor.

Murdiyarso, D., M. Skutsch, M. Guariguara, M. Kanninen, C. Luttrell, P. Verweij and O. S. Martins. 2008. Moving Ahead with REDD Issues, Options and Implications: How Do We Measure and Monitor Forest Degradation? CIFOR, Bogor.

Mankiw, N.G. 2000. Macroeconomics. $4^{\text {th }}$ Ed. Worth Publishers, New York.

Norrbin, S. 2000. What Have We Learned from Empirical Tests of the Monetary Transmission Effect? Department of Economics, Florida State Univ., Tallahassee.
Pusat Inventarisasi dan Perpetaan Kehutanan. 2008. Penghitungan Deforestasi Indonesia Tahun 2008. Badan Planologi Kehutanan, Departemen Kehutanan, Jakarta.

Pangestu, M.E. 1986. The Effects of an Oil Boom on a Small Oil Exporting Country: The Case of Indonesia. Dissertation. Univ. of California, Davis.

Suranovic, S.M. 2008. International Finance: Theory and Policy Analysis. Http://internationalecon.com/Finance /F-overview.php.

Wunder, S. and B. Verbist. 2003. The Impact of Trade and Macroeconomic Policies on Frontier Deforestation. ASB Lecture Note 13. World Agroforestry Centre ICRAF Southeast Asia Regional Office, Bogor. 
Lampiran 1. Model ekonometrika deforestasi dan degradasi hutan alam Appendix 1. Econometric model of natural forest degradation and deforestation

I. Blok makroekonomi (Macroeconomic block)

$\mathrm{C}_{\mathrm{t}}=\mathrm{a}_{0}+\mathrm{a}_{1}\left(\mathrm{YD}_{\mathrm{t}}\right)+\mathrm{a}_{2} \mathrm{R}_{\mathrm{t}}+?{ }_{1}$

$\mathrm{T}_{\mathrm{t}}=\mathrm{b}_{0}+\mathrm{b}_{1} \mathrm{Y}_{\mathrm{t}}+\mathrm{b}_{2} \mathrm{R}_{\mathrm{t}}+\mathrm{b}_{3} \mathrm{~T}_{\mathrm{t}-1}+?{ }_{2 \mathrm{t}}$

$\mathrm{G}_{\mathrm{t}}=\mathrm{c}_{0}+\mathrm{c}_{1} \mathrm{~T}_{\mathrm{t}}+\mathrm{c}_{2} \mathrm{Oil}_{\mathrm{t}}^{\mathrm{P}}+\mathrm{c}_{3} \mathrm{G}_{\mathrm{t}-1}+$ ? $3 \mathrm{t}$

$\mathrm{I}_{\mathrm{t}}=\mathrm{d}_{0}+\mathrm{d}_{1} \mathrm{R}_{\mathrm{t}-2}+\mathrm{d}_{2} \mathrm{Y}_{\mathrm{t}}+\mathrm{d}_{3}$ KRISIS $_{\mathrm{t}}+\mathrm{d}_{4} \mathrm{I}_{\mathrm{t}-1}+?{ }_{4 \mathrm{t}}$

$\mathrm{NX}_{\mathrm{t}}=\mathrm{e}_{0}+\mathrm{e}_{1}\left(\mathrm{e}_{\mathrm{t}}{ }^{*} \mathrm{IHK}_{\mathrm{t}} / \mathrm{US}^{\mathrm{CPI}}{ }_{\mathrm{t}}\right)+\mathrm{e}_{2} \mathrm{Y}_{\mathrm{t}}+\mathrm{e}_{3} \mathrm{Oil}^{\mathrm{P}_{\mathrm{t}}}+\mathrm{c}_{4} \mathrm{NX}_{\mathrm{t}-1}+?{ }_{5 \mathrm{t}}$

$\mathrm{r}_{\mathrm{t}}=\mathrm{f}_{0}+\mathrm{f}_{1} \mathrm{MS}_{\mathrm{t}-1}+\mathrm{f}_{2}\left(\mathrm{IHK}_{\mathrm{t}}-\mathrm{IHK}_{\mathrm{t}-1}\right)+\mathrm{f}_{3}$ ? $^{\mathrm{E}_{\mathrm{t}}}+\mathrm{f}_{4} \mathrm{KRISIS}_{\mathrm{t}}+\mathrm{f}_{5} \mathrm{FER}_{\mathrm{t}}+\mathrm{f}_{6} \mathrm{r}_{\mathrm{t}-1}+$ ? $_{6 \mathrm{t}}$

$\mathrm{IHK}_{\mathrm{t}}=\mathrm{g}_{0}+\mathrm{g}_{1} \mathrm{Y}_{\mathrm{t}-1}+\mathrm{g}_{2} \mathrm{IHK}_{\mathrm{t}-1}+$ ? ${ }_{\mathrm{t}}$

$e_{t}=h_{0}+h_{1}$ UIP $_{t}+h_{2} N_{\text {t }-1}+h_{3}$ MS $_{t}+h_{4}$ KRISIS $_{t}+h_{5} e_{t-1}+?{ }_{8 \mathrm{t}}$

$\mathrm{LD}_{\mathrm{t}}=\mathrm{i}_{0}+\mathrm{i}_{1} \mathrm{~W}_{\mathrm{t}-1}+\mathrm{i}_{2} \mathrm{Y}_{\mathrm{t}}+\mathrm{i}_{3} \mathrm{LD}_{\mathrm{t}-1}+$ ? ${ }_{\mathrm{t}}$

$\mathrm{Y}_{\mathrm{t}}=\mathrm{C}_{\mathrm{t}}+\mathrm{I}_{\mathrm{t}}+\mathrm{G}_{\mathrm{t}}+\mathrm{NX}_{\mathrm{t}}$

$\mathrm{R}_{\mathrm{t}}=\mathrm{r}_{\mathrm{t}}-$ ? $_{\mathrm{t}}$

$\mathrm{UIP}_{\mathrm{t}}=\mathrm{R}_{\mathrm{t}}-\mathrm{R}_{\mathrm{t}}^{\mathrm{US}}$

$\mathrm{UL}_{\mathrm{t}}=\mathrm{LS}_{\mathrm{t}}-\mathrm{LD}_{\mathrm{t}}$

II. Blok deforestasi (Deforestation block)

A. Deforestasi untuk a real HTI (Deforestation for timber estate)

$\mathrm{DF}^{\mathrm{HTI}}{ }_{\mathrm{t}}=\mathrm{j}_{0}+\mathrm{j}_{1} \mathrm{P}^{\mathrm{XPULP}} \mathrm{t}_{-2}+\mathrm{j}_{2} \mathrm{P}^{\mathrm{KHTJ}} \mathrm{t}_{\mathrm{t}}+\mathrm{j}_{3}\left(\mathrm{R}_{\mathrm{t}}-\mathrm{R}_{\mathrm{t}-2}\right)+\mathrm{j}_{4} \mathrm{~W}_{\mathrm{t}}+\mathrm{j}_{5} \mathrm{P}^{\mathrm{BBM}_{\mathrm{t}}}+\mathrm{j}_{6} \mathrm{P}^{\mathrm{XKR}}{ }_{\mathrm{t}}$ $+j_{7} \mathrm{PXMSW}_{t}+\mathrm{j}_{8} \mathrm{P}^{\mathrm{XKL}_{t}}+\mathrm{j}_{9} \mathrm{GP}^{\mathrm{HTT}}{ }_{\mathrm{t}}+\mathrm{j}_{10} \mathrm{~A}^{\mathrm{HTT}} \mathrm{t}_{\mathrm{t}-1}+?{ }_{10 t}$

$S^{\mathrm{KHTI}}{ }_{\mathrm{t}}=\mathrm{k}_{0}+\mathrm{k}_{1} \mathrm{P}^{\mathrm{KHTI}}{ }_{t}+\mathrm{k}_{2} \mathrm{R}_{\mathrm{t}}+\mathrm{k}_{3} \mathrm{q}^{\mathrm{HTI}}{ }_{\mathrm{t}}+\mathrm{k}_{4} \mathrm{~A}^{\mathrm{HTI}_{\mathrm{t}}}+\mathrm{i}_{5} \mathrm{~S}^{\mathrm{KHTI}}{ }_{\mathrm{t}-1}+?{ }_{11} \mathrm{t}$

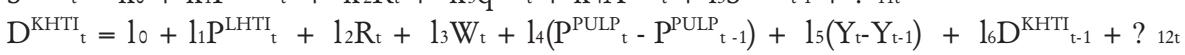

$\mathrm{S}_{\mathrm{KHTT}}=\mathrm{D}_{\mathrm{KHTI}}$

$\mathrm{P}_{\mathrm{t}}^{\mathrm{KHTI}}=\mathrm{m}_{0}+\mathrm{m}_{1}\left(\mathrm{P}^{\mathrm{XPULP}}{ }_{\mathrm{t}-\mathrm{P}^{\mathrm{XPULP}}}{ }_{\mathrm{t}-1}\right)+\mathrm{m}_{2} \mathrm{P}^{\mathrm{KHAt}}+\mathrm{m}_{3} \mathrm{~S}^{\mathrm{KHTI}}{ }_{\mathrm{t}-1}+\mathrm{m}_{4} \mathrm{P}_{\mathrm{K}-1}^{\mathrm{KHTI}}+?{ }_{13 \mathrm{t}}$

B. Deforestasi untuk areal s awit (Deforestation for palm o il plantation)

$\mathrm{DF}^{\mathrm{SW}}{ }_{\mathrm{t}}=\mathrm{n}_{0}+\mathrm{n}_{1} \mathrm{P}^{\mathrm{XMSW}}{ }_{\mathrm{t}-2}+\mathrm{n}_{2} \mathrm{P}^{\mathrm{BSW}}{ }_{\mathrm{t}}+\mathrm{n}_{3} \mathrm{R}_{\mathrm{t}-3}+\mathrm{n}_{4} \mathrm{~W}_{\mathrm{t}}+\mathrm{n}_{5} \mathrm{P}^{\mathrm{KHTI}}{ }_{\mathrm{t}-1}+\mathrm{n}_{6} \mathrm{P}^{\mathrm{KHA}}{ }_{\mathrm{t}-1}+\mathrm{n}_{7} \mathrm{~A}^{\mathrm{TSW}}{ }_{\mathrm{t}-1}+?{ }_{14 \mathrm{t}}$

$\mathrm{S}^{\mathrm{BSW}_{\mathrm{t}}=\mathrm{O} 0}+\mathrm{O}_{1} \mathrm{P}^{\mathrm{BSW}} \mathrm{t}_{\mathrm{t}}+\mathrm{O}_{2} \mathrm{R}_{\mathrm{t}}+\mathrm{O}_{3} \mathrm{q}^{\mathrm{BSW}}{ }_{\mathrm{t}}+\mathrm{O}_{4} \mathrm{~A}^{\mathrm{TSW}}{ }_{\mathrm{t}}+\mathrm{O}_{5} \mathrm{~S}^{\mathrm{BSW}} \mathrm{t}_{\mathrm{t}-1}+?{ }_{15 t}$

$\mathrm{D}^{\mathrm{BSW}}{ }_{\mathrm{t}}=\mathrm{p}_{0}+\mathrm{p}_{1} \mathrm{P}^{\mathrm{BSW}}{ }_{\mathrm{t}}+\mathrm{p}_{2} \mathrm{R}_{\mathrm{t}}+\mathrm{p}_{3} \mathrm{~W}_{\mathrm{t}}+\mathrm{p}_{4} \mathrm{P}^{\mathrm{DMSW}} \mathrm{t}+\mathrm{p}_{5} \mathrm{Y}_{\mathrm{t}}+\mathrm{p}_{6} \mathrm{D}^{\mathrm{BSW}}{ }_{\mathrm{t}-1}+?{ }_{16 \mathrm{t}}$

$\mathrm{S}^{\mathrm{BSW}}{ }_{\mathrm{t}}=\mathrm{D}^{\mathrm{BSW}}{ }_{\mathrm{t}}$

$\mathrm{P}^{\mathrm{BSW}}{ }_{\mathrm{t}}=\mathrm{q} 0+\mathrm{q}_{1} \mathrm{P}^{\mathrm{XMSW}}{ }_{\mathrm{t}}+\mathrm{q}_{2} \mathrm{D}^{\mathrm{BSW}}{ }_{\mathrm{t}}+\mathrm{q}_{3} \mathrm{P}^{\mathrm{BSW}}{ }_{\mathrm{t}-1}+?{ }_{17 \mathrm{t}}$

C. Deforestasi untuk areal $\mathrm{k}$ aret Deforestation for rubber plantation)

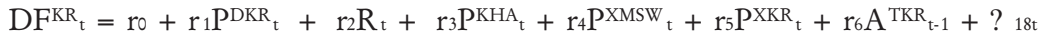

$\mathrm{S}^{\mathrm{KR}}{ }_{\mathrm{t}}=\mathrm{s}_{0}+\mathrm{s}_{1} \mathrm{P}^{\mathrm{DKR}{ }_{\mathrm{t}}}+\mathrm{s}_{2} \mathrm{R}_{\mathrm{t}}+\mathrm{s}_{3} \mathrm{q}^{\mathrm{KR}}{ }_{\mathrm{t}}+\mathrm{s}_{4} \mathrm{~A}^{\mathrm{TKR}}{ }_{\mathrm{t}}+\mathrm{s}_{5} \mathrm{~S}^{\mathrm{KR}}{ }_{\mathrm{t}-1}+?{ }_{19 t}$

$D^{D K R}{ }_{t}=t_{0}+t_{1} P^{D K R}{ }_{t}+t_{2} R_{t-1}+t_{3} W_{t-1}+t_{4}\left(Y_{t}-Y_{t-1}\right)+t_{6} D^{D K R}-1+? 20 t$

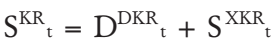

$\mathrm{P}^{\mathrm{DKR}_{\mathrm{t}}}=\mathrm{v}_{0}+\mathrm{v}_{1}\left(\mathrm{P}^{\mathrm{XKR}}{ }_{\mathrm{t}-} \mathrm{P}^{\mathrm{XKR}} \mathrm{t}_{\mathrm{t}-1}\right)+\mathrm{v}_{2} \mathrm{~S}^{\mathrm{XKR}_{\mathrm{t}}}+\mathrm{v}_{3} \mathrm{~S}^{\mathrm{KR}}{ }_{\mathrm{t}}+\mathrm{v}_{4} \mathrm{Pt}^{\mathrm{DKR}}{ }_{\mathrm{t}-1}+?{ }_{22 \mathrm{t}}$

D. Deforestasi untuk areal padi (Deforestation for paddy field)

$\mathrm{DF}^{\mathrm{PD}_{t}}=\mathrm{w}_{0}+\mathrm{w}_{1} \mathrm{P}^{\mathrm{GKG}}{ }_{\mathrm{t}}+\mathrm{w}_{2} \mathrm{P}^{\mathrm{HPP}}{ }_{\mathrm{t}}+\mathrm{w}_{3} \mathrm{R}_{\mathrm{t}}+\mathrm{w}_{4} \mathrm{P}^{\mathrm{BBM}_{\mathrm{t}}}+\mathrm{w}_{5} \mathrm{P}^{\mathrm{KHA}}{ }_{\mathrm{t}}+\mathrm{w}_{6} \mathrm{P}^{\mathrm{KHTI}}{ }_{\mathrm{t}}+\mathrm{w}_{7} \mathrm{POP}_{\mathrm{t}}+\mathrm{w}_{8} \mathrm{~A}^{\mathrm{TPD}}{ }_{\mathrm{t}-1}+?{ }_{23 t}$

$\mathrm{S}^{\mathrm{GKG}_{\mathrm{t}}}=\mathrm{x}_{0}+\mathrm{x}_{1} \mathrm{P}^{\mathrm{GKG}}{ }_{\mathrm{t}}+\mathrm{x}_{2} \mathrm{R}_{\mathrm{t}}+\mathrm{x}_{3} \mathrm{P}^{\mathrm{BBM}}{ }_{\mathrm{t}}+\mathrm{x}_{4} \mathrm{q}^{\mathrm{PD}_{\mathrm{t}}}+\mathrm{x}_{5} \mathrm{SD}^{\mathrm{PD}-1}+?{ }_{24 t}$

$\mathrm{D}^{\mathrm{GKG}} \mathrm{t}_{\mathrm{t}}=\mathrm{y}_{0}+\mathrm{y}_{1} \mathrm{P}_{\mathrm{HPP}}^{\mathrm{HP}}+\mathrm{y}_{2} \mathrm{R}_{\mathrm{t}}+\mathrm{y}_{3} \mathrm{P}^{\mathrm{BBM}}{ }_{\mathrm{t}}+\mathrm{y}_{4} \mathrm{P}^{\mathrm{DBR}}{ }_{\mathrm{t}}+\mathrm{y}_{5} \mathrm{Y}_{\mathrm{t}}+\mathrm{y}_{6} \mathrm{D}^{\mathrm{GKG}} \mathrm{t}_{\mathrm{t}-1}+?{ }_{25 \mathrm{t}}$

$\mathrm{S}^{\mathrm{GKG}} \mathrm{t}_{\mathrm{t}}=\mathrm{D}^{\mathrm{GKG}} \mathrm{t}_{\mathrm{t}}$

$\mathrm{P}^{\mathrm{GKG}} \mathrm{t}=\mathrm{z}_{0}+\mathrm{z}_{1}\left(\mathrm{P}_{\mathrm{HPP}}-\mathrm{P}_{\mathrm{HPP}}^{\mathrm{HP}-1}\right)+\mathrm{z}_{2} \mathrm{~S}^{\mathrm{GKG}} \mathrm{t}+\mathrm{z}_{3} \mathrm{P}^{\mathrm{GKG}} \mathrm{t}-1+?{ }_{26 \mathrm{t}}$

E. Total Deforestasi untuk Areal HTI, Sawit, Karet dan Padi (Deforestation Total)

$\mathrm{TDF}_{\mathrm{t}}=\mathrm{DF}_{\mathrm{t}}^{\mathrm{HTI}}+\mathrm{DF}_{\mathrm{t}}^{\mathrm{SW}}+\mathrm{DF}_{\mathrm{t}}^{\mathrm{KR}_{\mathrm{t}}}+\mathrm{DF}_{\mathrm{t}}^{\mathrm{PD}_{\mathrm{t}}}$

III. Blok degradasi (Degradation block)

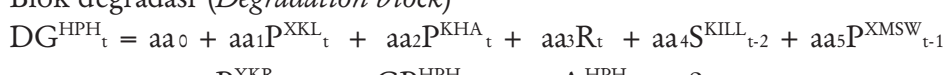
$+a_{6} \mathrm{PXKR}_{\mathrm{t}-1}+\mathrm{aa}_{7} \mathrm{GP}_{\mathrm{HPH}}+\mathrm{aa}_{8} \mathrm{~A}^{\mathrm{HPH}} \mathrm{t}-1+? 27 \mathrm{t}$

$\mathrm{S}^{\mathrm{KILL}}{ }_{\mathrm{t}}=\mathrm{bb}_{0}+\mathrm{bb}_{1} \mathrm{P}_{\mathrm{KHA}}^{\mathrm{KHA}}+\mathrm{bb}_{2} \mathrm{R}_{t}+\mathrm{bb}_{3} \mathrm{P}^{\mathrm{BBM}}{ }_{\mathrm{t}}+\mathrm{bb}_{4} \mathrm{DR}_{\mathrm{t}}+\mathrm{bb}_{5} \mathrm{q}_{\mathrm{t}}^{\mathrm{HA}}+\mathrm{bb}_{6} \mathrm{GP}^{\mathrm{KUM}}{ }_{t}+\mathrm{bb}_{7} \mathrm{SLL}_{\mathrm{t}-1}+?{ }_{28 \mathrm{t}}$

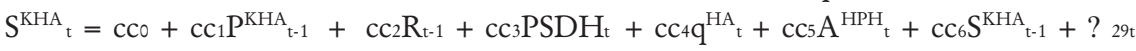

$\mathrm{D}^{\mathrm{KHAKG}}{ }_{\mathrm{t}}=\mathrm{dd}_{0}+\mathrm{dd}_{1} \mathrm{P}_{\mathrm{K}}^{\mathrm{KHA}}+\mathrm{dd}_{2} \mathrm{P}_{\mathrm{t}}^{\mathrm{KHTI}}+\mathrm{dd}_{3} \mathrm{R}_{\mathrm{t}}+\mathrm{dd}_{4} \mathrm{~W}_{\mathrm{t}}+\mathrm{dd}_{5} \mathrm{Y}_{\mathrm{t}}+\mathrm{dd}_{6} \mathrm{D}^{\mathrm{KHAKG}}{ }_{\mathrm{t}-1}+?{ }_{30 \mathrm{t}}$

$\mathrm{D}^{\mathrm{KHAKL}_{\mathrm{t}}}=$ eeo + ee $\mathrm{P}^{\mathrm{KHA}_{\mathrm{t}}}+\mathrm{ee}_{2} \mathrm{PKHTI}_{\mathrm{t}}+\mathrm{ee}_{3} \mathrm{R}_{\mathrm{t}-1}+\mathrm{ee}_{4} \mathrm{~W}_{\mathrm{t}}+\mathrm{ee}_{5} \mathrm{PXKL}_{\mathrm{t}}$

+ ee $6\left(\mathrm{Y}_{\mathrm{t}}-\mathrm{Y}_{\mathrm{t}-1}\right)+\mathrm{ee}_{6} \mathrm{D}^{\mathrm{KHAKL}} \mathrm{t}-1_{1}+?{ }_{31 \mathrm{t}}$

$S^{K H A}{ }_{t}+S^{K I L L}{ }_{t}=D^{K^{K H K G}}+D^{K^{K H A K L}}{ }_{t}+S^{\mathrm{XKHA}_{t}}$

$\mathrm{P}^{\mathrm{KHA}}{ }_{\mathrm{t}}=\mathrm{ff} \mathrm{f}+\mathrm{ff}_{1} \mathrm{P}^{\mathrm{XKL}}{ }_{\mathrm{t}}+\mathrm{ff}_{2}\left(\mathrm{~S}^{\mathrm{KILL}}{ }_{\mathrm{t}}+\mathrm{S}^{\mathrm{KHA}} \mathrm{t}\right)+\mathrm{ff}_{3} \mathrm{P}^{\mathrm{KHA}}{ }_{\mathrm{t}-1}+?{ }_{32 \mathrm{t}}$ 


\section{Lampiran 2. Deskripsi peubah yang digunakan dalam pendugaan model}

\section{Appendix 2. Variables description used in model estimation}

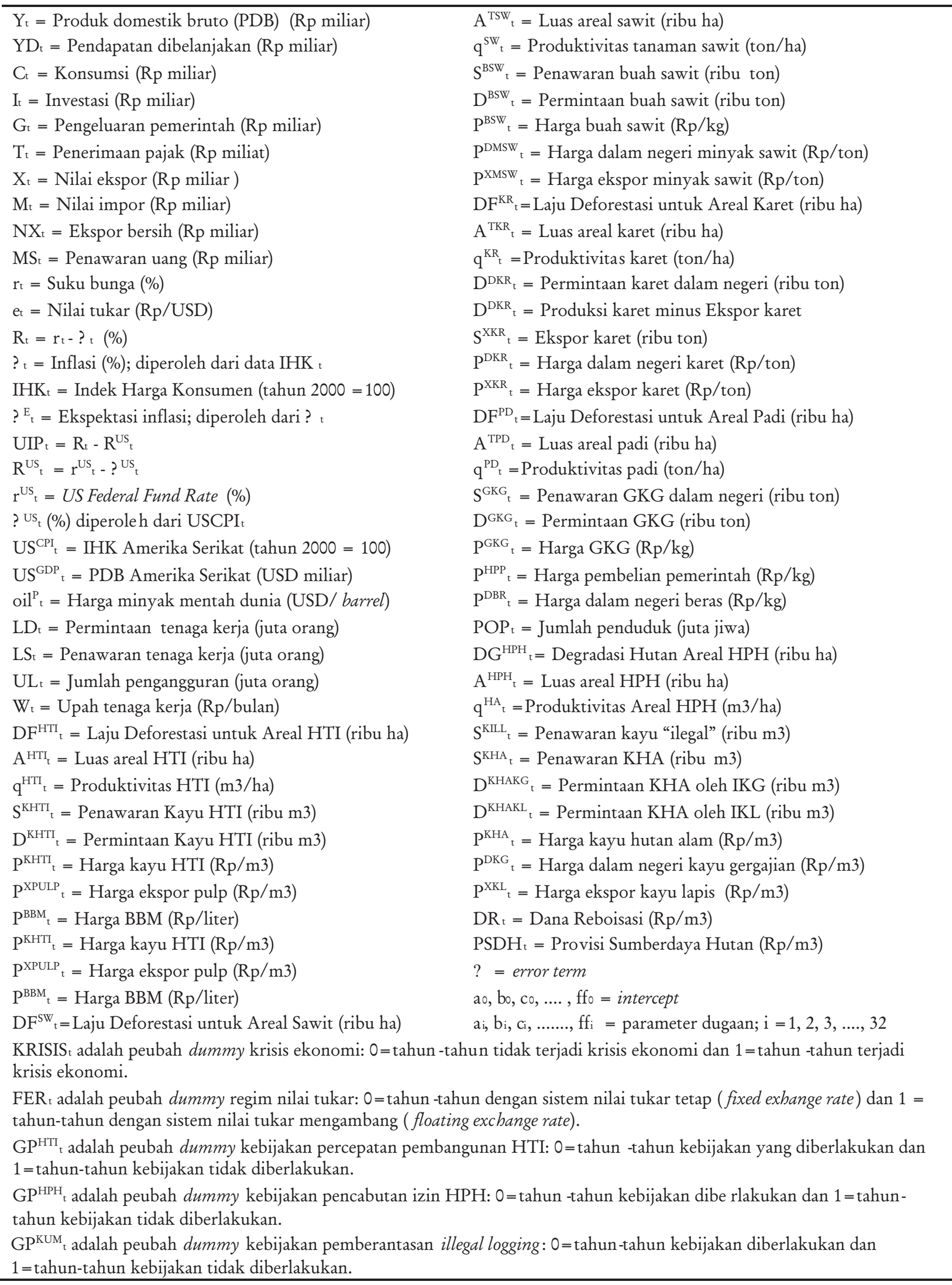

